\title{
Recent trends in Inner Asian forest dynamics to temperature and precipitation indicate high sensitivity to climate change
}

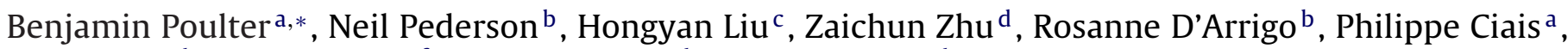 \\ Nicole Davi ${ }^{\mathrm{b}}$, David Frank ${ }^{\mathrm{e}, \mathrm{f}}$, Caroline Leland ${ }^{\mathrm{b}}$, Ranga Myneni ${ }^{\mathrm{d}}$, Shilong Piao ${ }^{\mathrm{c}}$, Tao Wang $^{\mathrm{a}}$ \\ a Laboratoire des Sciences du Climat et de l'Environnement, LSCE CEA CNRS UVSQ 91191 Gif Sur Yvette, France \\ b Tree Ring Laboratory of Lamont-Doherty Earth Observatory and Columbia University, 61 Route 9w, Palisades, NY 10964, USA \\ c College of Urban and Environmental Sciences, Peking University, Beijing 100871, China \\ d Department of Geography and Environment, Boston University, 675 Commonwealth Avenue, Boston, MA 02215, USA \\ e Swiss Federal Research Institute WSL, Dendroclimatology, Zürcherstrasse 111, Birmensdorf 8903, Switzerland \\ ${ }^{f}$ Oeschger Centre for Climate Change Research, University of Bern, Bern, Switzerland
}

\section{A R T I C L E I N F O}

\section{Article history:}

Received 4 July 2012

Received in revised form

11 December 2012

Accepted 17 December 2012

\section{Keywords:}

Semi-arid forest

Remote sensing

Dendrochronology

Dynamic global vegetation model

Climate change

Carbon cycle

\begin{abstract}
A B S T R A C T
Semi-arid ecosystems play an important role in regulating global climate with the fate of these ecosystems in the Anthropocene depending upon interactions among temperature, precipitation, and $\mathrm{CO}_{2}$. However, in cool-arid environments, precipitation is not the only limitation to forest productivity. Interactions between changes in precipitation and air temperature may enhance soil moisture stress while simultaneously extending growing season length, with unclear consequences for net carbon uptake. This study evaluates recent trends in productivity and phenology of Inner Asian forests (in Mongolia and Northern China) using satellite remote sensing, dendrochronology, and dynamic global vegetation model (DGVM) simulations to quantify the sensitivity of forest dynamics to decadal climate variability and trends. Trends in photosynthetically active radiation fraction (FPAR) between 1982 and 2010 show a greening of about $7 \%$ of the region in spring (March, April, May), and 3\% of the area 'browning' during summertime (June, July, August). These satellite observations of FPAR are corroborated by trends in NPP simulated by the LPJ DGVM. Spring greening trends in FPAR are mainly explained by long-term trends in precipitation whereas summer browning trends are correlated with decreasing precipitation. Tree ring data from 25 sites confirm annual growth increments are mainly limited by summer precipitation (June, July, August) in Mongolia, and spring precipitation in northern China (March, April, May), with relatively weak prioryear lag effects. An ensemble of climate projections from the IPCC CMIP3 models indicates that warming temperatures (spring, summer) are expected to be associated with higher summer precipitation, which combined with $\mathrm{CO}_{2}$ causes large increases in NPP and possibly even greater forest cover in the Mongolian steppe. In the absence of a strong direct $\mathrm{CO}_{2}$ fertilization effect on plant growth (e.g., due to nutrient limitation), water stress or decreased carbon gain from higher autotrophic respiration results in decreased productivity and loss of forest cover. The fate of these semi-arid ecosystems thus appears to hinge upon the magnitude and subtleties of $\mathrm{CO}_{2}$ fertilization effects, for which experimental observations in arid systems are needed to test and refine vegetation models.
\end{abstract}

(C) 2012 Elsevier B.V. All rights reserved.

\section{Introduction}

Semi-arid ecosystems cover between 17 and 30\% of the global land surface and have climatic regimes characterized by low mean annual precipitation ( $\left.<650 \mathrm{~mm} \mathrm{yr}^{-1}\right)$ and vegetation adapted to dry soil conditions (Rotenberg and Yakir, 2010; Sankaran et al., 2005). Within Central Asia, the Köppen-Geiger arid system biome

\footnotetext{
* Corresponding author.

E-mail address: benjamin.poulter@lsce.ipsl.fr (B. Poulter).
}

is further subdivided based on mean annual air temperature (Peel et al., 2007), with Mongolia generally dominated by 'cold-steppe' vegetation, and Northern China by 'warm desert'. Despite lowregional annual precipitation, the climatic temperature gradient within Central Asia exerts a large effect on hydrology and ecosystem characteristics as reflected by shrub-desert vegetation in the south and taiga and boreal forest vegetation in the north. Projected changes in air temperature from climate change may be favorable for forest productivity in the north, but cause increased soil moisture limitations in the south. Thus the interactions between temperature and precipitation, and possible increases in 
water-use efficiency from elevated $\mathrm{CO}_{2}$ (Penuelas et al., 2011), suggest a complex response of vegetation dynamics to climate change within Inner Asia.

Decadal-scale climate variability and trends have already been observed in forest inventory, tree ring, and satellite data to have a strong influence on semi-arid vegetation dynamics. Over the past 40 years, Inner Asia and Northern China have experienced simultaneously a warming trend $\left(0.04{ }^{\circ} \mathrm{Cyr}^{-1}\right)$ and decreasing precipitation (Piao et al., 2010a). Large-scale forest mortality has been observed in Pinus forests in Southwest China and in Picea forests in Southern Russia as a consequence of the more frequent recent droughts (Allen et al., 2010; Davi et al., 2006). In addition, satellitederived observations have shown high ecosystem sensitivity to decadal climate variability, with an increase in desert area during the past decade (Jeong et al., 2011; Piao et al., 2005). Dynamic global vegetation model (DGVM) results also similarly suggest that recent droughts have likely weakened the carbon sink strength of Northern China and Mongolia, although the underlying mechanisms remain unclear (Piao et al., 2012).

The sensitivity of ecosystem dynamics to contemporary climate variability can provide a constraint for evaluating the response of ecosystems to future climate change (Babst et al., 2012). This constraint can be especially important for the development, application and benchmarking of dynamic global vegetation models that combine biogeography and biogeochemistry to evaluate changes in ecosystems from climate, $\mathrm{CO}_{2}$, and disturbance (Luo et al., 2012; Prentice et al., 2007). For example, results from a recent study in north-east Asia, where an ensemble of DGVM models were forced by contemporary climate (Piao et al., 2010b), revealed large differences in the inter-model sensitivity of carbon fluxes to temperature and precipitation. Among the models, simulated net primary production (NPP) was more sensitive to precipitation than temperature for the LPJ-DGVM, compared to higher temperature sensitivity for SDGVM, and an intermediate response for ORCHIDEE. Such inter-model differences have large implications for interpreting future climate impacts that imply large regional changes in fire and biome distributions in the future (Moritz et al., 2012; Scholze et al., 2006).

This study addresses regional-scale patterns of inter-annual climate sensitivity of semi-arid ecosystem productivity in Inner Asia by comparing satellite and tree ring records of forest dynamics with DGVM model simulations. Satellite observations of the fraction of photosynthetically active radiation absorbed by vegetation (FPAR) from 1982 to 2010 provide a long-term record of regional forest and grassland dynamics (at 8-km resolution) and their response to 30 years of monthly climate variability and trends. Variability in tree growth recorded by the formation of annual tree rings provides insight into seasonal controls of temperature and precipitation. With these observations used as benchmarks, we evaluate modeled changes in transient NPP and annual tree cover for 1982-2010, and then discuss possible climate impacts from an ensemble of model simulations for the 21st century.

\subsection{Hypotheses}

The study is designed to test three hypotheses related to ecosystem dynamics and climate sensitivity in Inner Asia. The hypotheses and their expected outcomes are:

1. Water limitation, and its effect on ecosystem productivity, becomes gradually more important as mean annual temperature increases.

a. Vegetation productivity in the southern region of Inner Asia will be observed to be mainly precipitation limited.

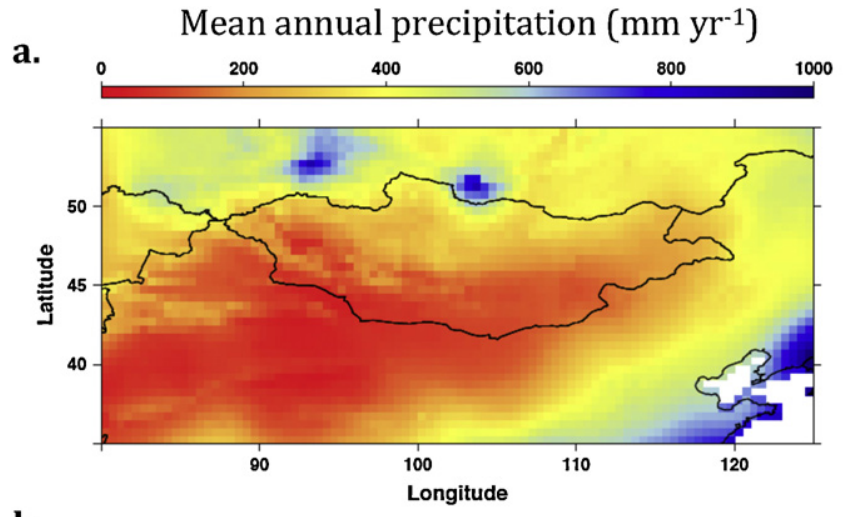

b.
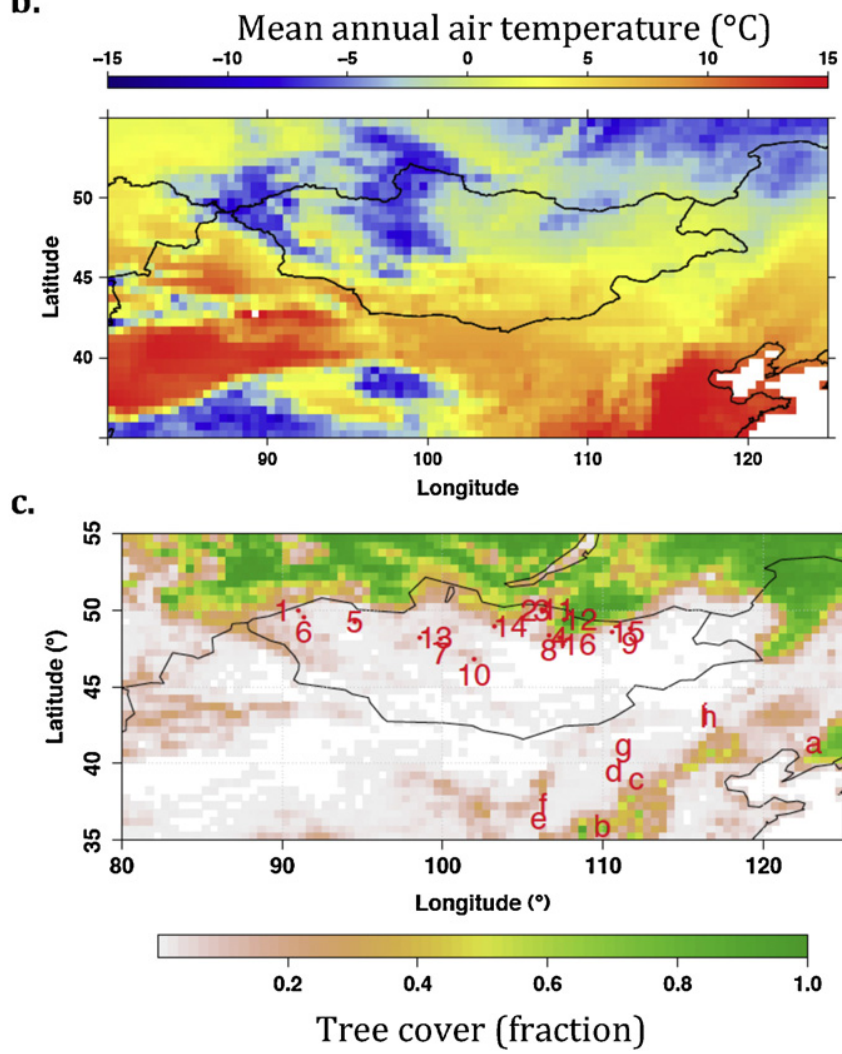

Fig. 1. Study area for the region of Inner Asia $\left(80^{\circ} \mathrm{E}, 125^{\circ} \mathrm{E}, 35^{\circ} \mathrm{N}, 55^{\circ} \mathrm{N}\right)$ illustrating (a) mean annual precipitation, (b) mean annual temperature, and (c) fractional tree cover with the locations of the tree ring records. The climate data are 1982-2009 annual means from CRU TS 3.1 and the tree cover data are derived from MODIS (Poulter et al., 2011).

b. Vegetation productivity in the northern region of Inner Asia will be observed to be mainly temperature limited.

2. Spatial patterns of climate sensitivity will show agreement between satellite FPAR and tree growth datasets.

a. Based on previous work of Piao et al. (2010b), the observed high-precipitation sensitivity of the LPJ DGVM will not capture latitudinal climate-by-vegetation sensitivity gradients.

3. Climate change projections from model simulations will alleviate temperature limitation on ecosystem productivity in the Northern region at the expense of increased drought stress in the Southern region.

a. Leaf-level stomatal conductance feedbacks with elevated atmospheric $\mathrm{CO}_{2}$ will moderate the response of ecosystems to drought stress. 
Table 1

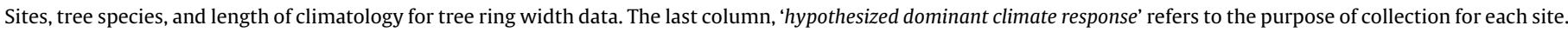

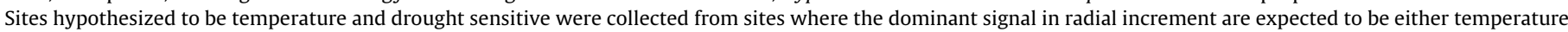
or drought. Mixed sensitivity refers to the idea that either precipitation or temperature is the dominant constraint on radial increment from year-to-year.

\begin{tabular}{|c|c|c|c|c|}
\hline Region & Species & Time period & Reference & Hypothesized climate response \\
\hline \multicolumn{5}{|l|}{ China } \\
\hline a. Qianshan & Pinus tabulaeformis & 1900-2003 & Chen et al. (2007) & No \\
\hline b. Shanxihuanglong & Pinus tabulaeformis & 1900-2002 & Cai et al. (2005) & data \\
\hline c. Ningwu & Pinus tabulaeformis & 1900-2001 & Yi et al. (2006) & \\
\hline d. Zgeq & Pinus tabulaeformis & $1900-2003$ & Shi et al. (2004) & \\
\hline e. XMS & Pinus tabulaeformis & 1900-2005 & Wang et al. (2009a) & \\
\hline f. Luoshan & Pinus tabulaeformis & $1900-2007$ & Wang et al. (2009b) & \\
\hline g. Daqingshan & Pinus tabulaeformis & 1900-1996 & Liu and Ma (1999) & \\
\hline h. YISNAS & Pinus tabulaeformis & 1900-2004 & Liang et al. (2007) & \\
\hline i. GQNAS & Pinus tabulaeformis & 1900-2004 & Liang et al. (2007) & \\
\hline \multicolumn{5}{|l|}{ Mongolia } \\
\hline 1. Biarum Uul & Larix sibirica & $1350-2005$ & Jacoby et al. (2003) & Temperature \\
\hline 2. Delger Khan Uul & Pinus sylvestris & 1710-2009 & Leland (2011) & Mixed \\
\hline 3. Dulaan Khan & Pinus sylvestris & 1653-2008 & Leland (2011) & Drought \\
\hline 4. Hentil Mountain & Larix sibirica & 996-2002 & Cook et al. (2010) & Temperature \\
\hline 5. Horin Bugatyun Davaa & Larix sibirica & 1265-1997 & D'Arrigo et al. (2000) & Temperature \\
\hline 6. Khalzan Khamar & Larix sibirica & 1326-1998 & D'Arrigo et al. (2000) & Temperature \\
\hline 7. Khorgo Lava Larch & Larix sibirica & 1340-2000 & Davi et al. (2006) & Drought \\
\hline 8. Narstain Davaa & Pinus sylvestris & 1740-2008 & Leland (2011) & Mixed \\
\hline 9. Onon Gol & Larix sibirica & $1576-2001$ & Davi et al. (2013) & Drought \\
\hline 10. Orkhon Gol Hushree & Larix sibirica & $1503-2009$ & Leland (2011) & Drought \\
\hline 11. Shaamar Mahan Nars & Pinus sylvestris & 1770-2008 & Leland (2011) & Drought \\
\hline 12. Shoorgobjyun Davaa & Pinus sylvestris & $1626-2008$ & Not published & Mixed \\
\hline 13. Sologotyin Davaa & Pinus sibirica & 558-1999 & D'Arrigo et al. (2001) & Temperature \\
\hline 14. Under Ulaan & Larix sibirica & 1510-2002 & Davi et al. (2006) & Drought \\
\hline 15. Urgun Nars & Pinus sylvestris & 1714-2009 & Pederson et al. (2001) & Drought \\
\hline 16. Zuun Mod & Larix sibirica & $1582-2000$ & Pederson et al. (2001) & Drought \\
\hline
\end{tabular}

\section{Methods}

\subsection{Contemporary climate (1982-2009) of Inner Asia}

Inner Asia includes the semi-arid regions of northern China, Mongolia, and parts of southern Russia, an area encompassing 7.8 million $\mathrm{km}^{2}$ (Fig. 1). Based on the Climatic Research Unit (CRU TS 3.1) dataset (Mitchell and Jones, 2005), mean annual precipitation (for 1982-2009, corresponding to the period overlapping the satellite-FPAR record) is $294 \mathrm{~mm} \mathrm{yr}^{-1}$, ranging between 15 and $996 \mathrm{mmyr}^{-1}$ across the entire region. About $75 \%$ of the precipitation occurs in spring and summer (March-August), with year-to-year variation in summertime precipitation up to $35 \%$. Winter precipitation is typically low and spatially variable (3-103 $\left.\mathrm{mm} \mathrm{yr}^{-1}\right)$, and snowfall, while low in some parts of Inner Asia, can elsewhere have an important regional role on the thermal insulation of soils, surface albedo, and soil moisture recharge during spring thaw (Peng et al., 2010; Vaganov et al., 1999). According to the CRU TS 3.1 dataset, mean annual air temperature varies widely across the region $\left(-11.5^{\circ} \mathrm{C}\right.$ to $15.3^{\circ} \mathrm{C}$, with a regional mean of $2.1^{\circ} \mathrm{C}$ ), with growing season temperature (June-August) ranging from $-0.2^{\circ} \mathrm{C}$ to $31.1^{\circ} \mathrm{C}$ (mean of $17.6^{\circ} \mathrm{C}$ ). Inter-annual variability of growing season temperature is around $12 \%$ of the long-term mean (1982-2009).

\subsection{Contemporary climate trends and anomalies}

Gridded ( 0.5 degree) temperature and precipitation trends were calculated for each of four seasons (December-February (DJF), March-May (MAM), June-August (JJA), and September-November (SON)) using monthly climate data from CRU TS 3.1. Mean seasonal temperature and total seasonal precipitation were calculated for each year and then the trend (and its significance) estimated as the slope from a simple linear regression. To compare with the tree ring records, monthly climate anomalies were calculated as the residual between the long-term monthly mean (1971-2000) and the observed monthly value. The monthly climate anomalies were then detrended with a cubic polynomial spline (with a frequency cut-off of 0.5) and used to compare with annual (detrended) tree-ring growth anomalies over the same time period (see Section 2.4). The detrending was performed to remove long-term trends in climate (and tree growth) that might inflate correlations between inter-annual climate and tree growth. Principal components analysis (PCA) was used to determine the spatial pattern, and relative importance, of the individual seasonal climate trends for three different time periods (1982-1990, 1991-2000, 2001-2009) and the long-term trend (1982-2009). The PCA was conducted on the correlation matrix of the eight climate trends ( 4 seasons $\times 2$ climate variables), which were first normalized to equal variance. Statistical analysis and data processing were conducted using CDO version 1.5.5 and $\mathrm{R}$ version 2.15.0.

\section{Table 2}

The eleven global climate model (and model mean) changes in precipitation and temperature for the study area between 2000 and 2100 (following the normalization to the CRU TS 3.1 period). The climate projections follow the SRES A2 storyline, which reach a global atmospheric $\mathrm{CO}_{2}$ concentration of $850 \mathrm{ppm}$ in the year 2100 . Mean annual air temperature is presently $2.1^{\circ} \mathrm{C}$ and mean annual temperature is $294 \mathrm{~mm} \mathrm{yr}^{-1}$.

\begin{tabular}{lll}
\hline Climate model & $\begin{array}{l}\text { Change in precipitation } \\
\text { between } 2000 \text { and } \\
2100\left(\mathrm{~mm} \mathrm{yr}^{-1}\right)\end{array}$ & $\begin{array}{l}\text { Change in temperature } \\
\text { between } 2000 \text { and } \\
2100\left({ }^{\circ} \mathrm{Cyr}^{-1}\right)\end{array}$ \\
\hline CCCMA CGM 3.1 & 69.2 & 4.4 \\
CSIRO MK 3.5 & 43.6 & 5.1 \\
GFDL CM 2.1 & 6.1 & 5.1 \\
GISS ER & 7.0 & 4.1 \\
IPSL CM 4 & 50.5 & 5.6 \\
MIUB ECHO G & 37.5 & 6.0 \\
MPI ECHAM 5 & -6.1 & 5.8 \\
NCAR CCSM 3 & 93.6 & 5.2 \\
NCAR PCM 1 & 30.1 & 3.2 \\
UKMO HADCM3 & 60.6 & 5.5 \\
UKMO HADGEM1 & 58.0 & 5.2 \\
Model mean & 40.9 & 5.0 \\
\hline
\end{tabular}


Table 3

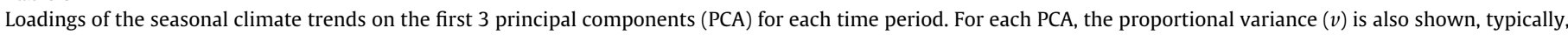

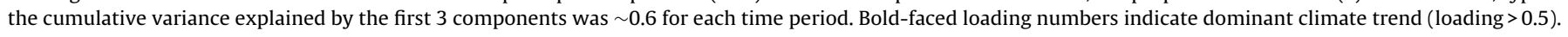

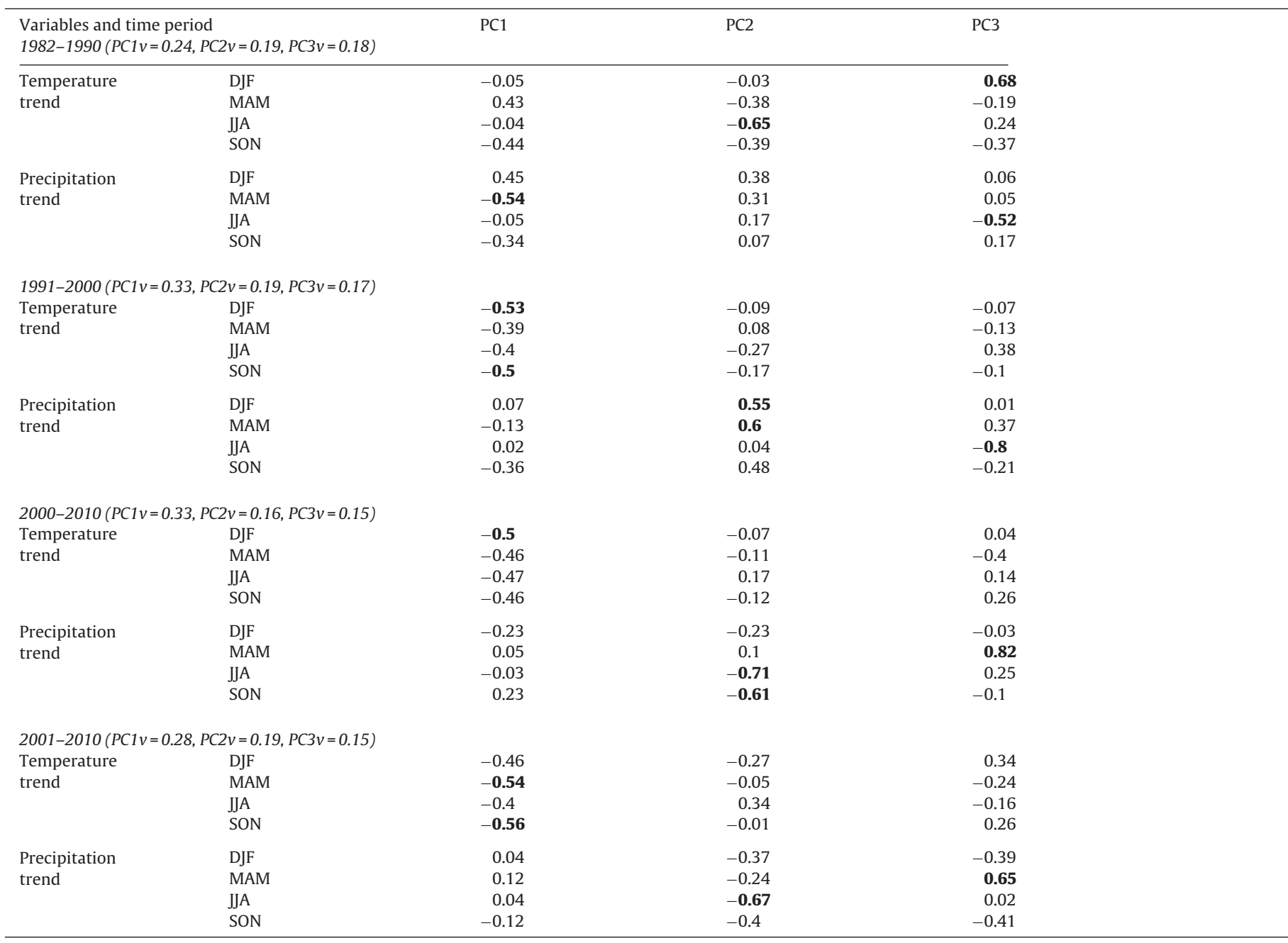

\subsection{Trends and sensitivity in satellite FPAR to climate}

FPAR remote sensing data were derived from the 3rd Generation Normalized Difference Vegetation Index (GIMMS NDVI3g) generated from the Advanced Very High Resolution Radiometers (AVHRR) onboard a series of NOAA satellites (Zhu et al., 2012; Tucker et al., 2005). This satellite product uses an artificial neural network to calculate AVHRR-FPAR values from AVHRR-NDVI and land-cover type using MODIS-FPAR as the training dataset. The resulting product has 15-day temporal resolution with 8$\mathrm{km}$ spatial resolution for the time period 1982-2010. From this product, we generated a maximum monthly composite to retain the highest quality monthly FPAR observations, and then seasonal means were estimated for DJF, MAM, JJA, and SON. The decadal and long-term seasonal trends (1982-2010, and decades within this period) and their statistical significance were estimated for each grid cell using simple linear regression. Pearson correlations were calculated between the JJA detrended FPAR values and the monthly-detrended climate residuals for an 18month window. The correlations between the climate and tree ring residuals were based on the 1982-2009 time period. To evaluate climate drivers responsible for FPAR trends, the Pearson correlation coefficient was calculated between the trends in FPAR with the each of the eight eigenvectors from the PCA analysis.

\subsection{Sensitivity of tree growth to climate}

The tree ring records include data from the International Tree Ring Database (ITRDB), and both published and unpublished collections from a total of 25 sites (see Table 1 for complete listing). For all datasets used in this study, the raw ring widths were cross-dated and re-standardized using methods including power transformation to stabilize variance (Cook and Kairiukstis, 1990). Data from low-density forest stands originally collected for climate reconstruction were 'conservatively standardized' using negative exponential, negative linear, or straight-line curves using the program ARSTAN (Cook, 1985) to preserve as much low-frequency variation as possible. Collections from more closed-canopy forests in Mongolia (Delger Khan Uul, Narstyin Davaa, and Shoorgobjyun Davaa), where tree competition and stand dynamics can significantly influence radial growth, were detrended a second time using the Friedman Super Smoother (Friedman, 1984), a data-adaptive flexible curve that adapts 'locally' to abrupt changes in ring width that resemble ecological processes and not climatic variation. The resulting indices of radial increment were combined into a robust mean chronology for each site ( $n \cong 15-20$ trees per site).

To determine the climate sensitivity of tree ring chronologies, residuals were calculated from the standard chronology (the chronology with growth trends removed) relative to a 1971-2000 mean baseline, the same baseline used to estimate the CRU TS 3.1 
a
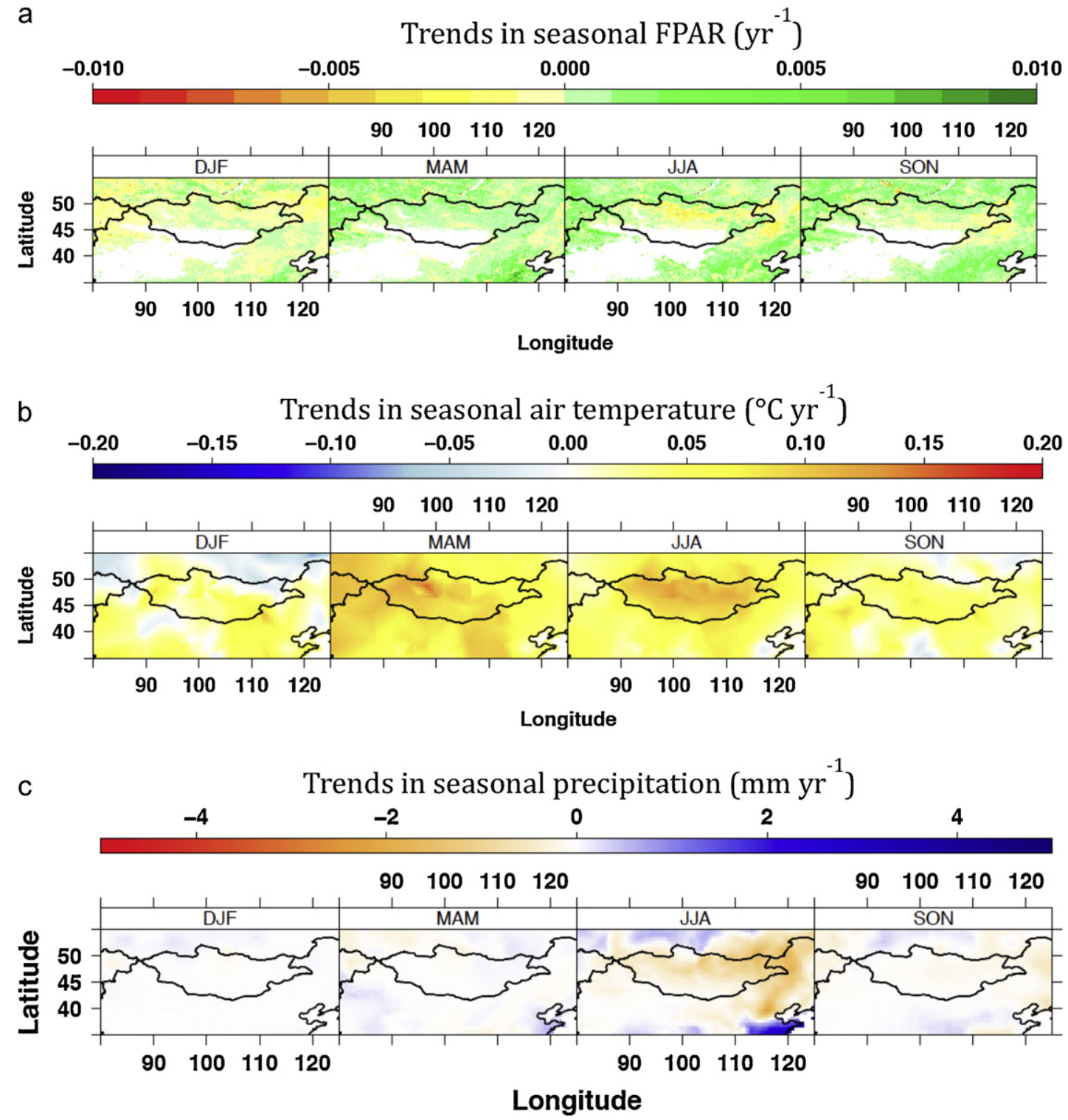

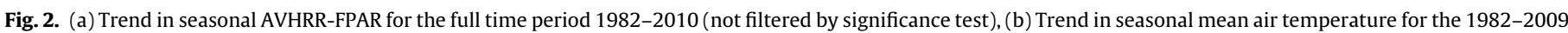
period, and (c) Trend in seasonal total precipitation for the 1982-2009 period.

climate anomalies. These residuals were then detrended using a cubic polynomial spline (with a frequency cut-off of 0.5 ) to remove the effects of long-term climate trends so that only inter-annual anomalies were analyzed (to minimize inflated climate correlations due to long-term trends, as discussed previously). Pearson correlations were calculated between the annual detrended tree ring residuals and the monthly-detrended climate residuals for an 18-month window. The correlations between the climate and tree ring residuals were based on the 1955-2009 time period, where the CRU TS 3.1 data were most reliable based on climate station density and record length from the surrounding region.

\subsection{Modeling climate sensitivity of NPP}

The LPJ dynamic global vegetation model (Sitch et al., 2003) was used to model ecosystem dynamics across Inner Asia. LPJ is a coupled biogeography and biogeochemistry model that simulates the distribution, carbon and water dynamics for nine plant functional types (PFT). LPJ has been extensively benchmarked for a range of ecosystems and variables, including long-term trends in northern hemisphere FPAR (Lucht et al., 2002) and net ecosystem exchange and gross primary production in temperate and tropical ecosystems (Poulter et al., 2009; Schaefer et al., 2012; Schwalm et al., 2010). The version used for this study includes a more detailed representation of hydrologic processes, which results in an improvement in model performance for hydrologic variables (Gerten et al., 2004), and the semi-empirical fire module, 'GlobFirm' (Thonicke et al., 2001). The numerical processes related to drought stress include belowground estimation of soil moisture and an explicit approach for coupling stomatal conductance with water demand and supply. Stomatal conductance is modeled using an approach developed by Haxeltine and Prentice (1996) coupled to the biochemical model of Farquhar et al. (1980) that is used to estimate photosynthesis. To calculate soil moisture, LPJ uses a two-bucket soil hydrology model, with a $0.5 \mathrm{~m}$ upper soil layer and a $1.0 \mathrm{~m}$ lower soil layer. Plant-water uptake is determined by root access to available 


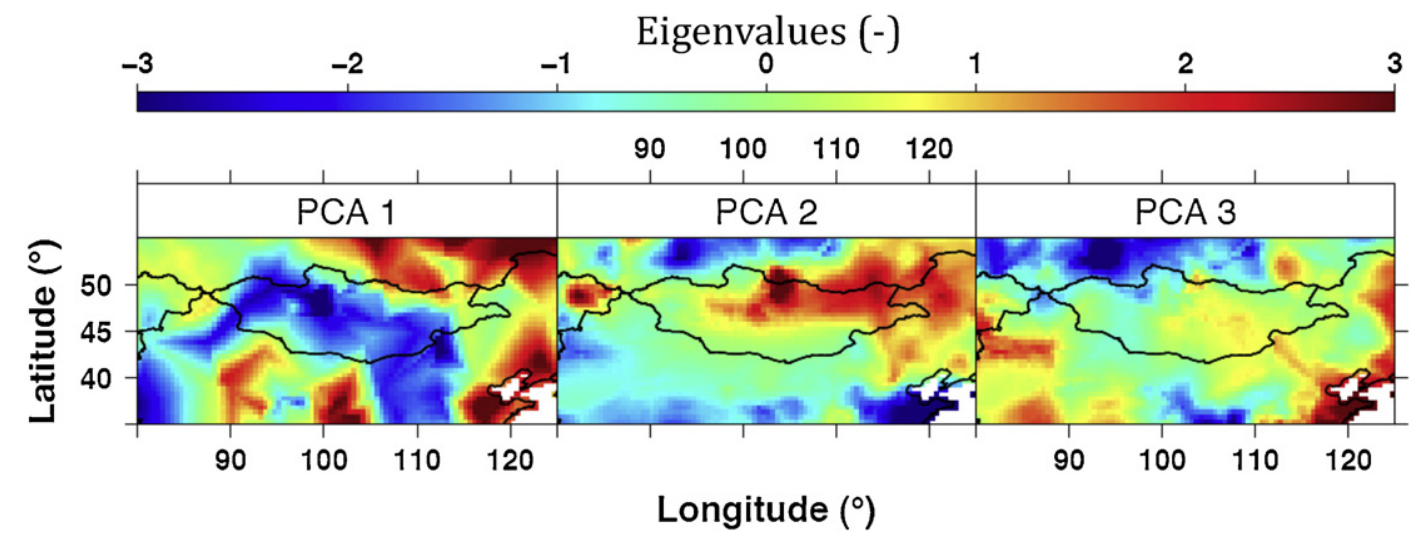

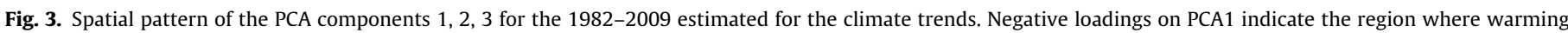

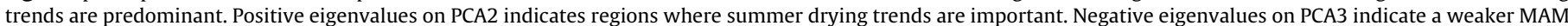
increase in precipitation.

soil water, which is proportional to PFT-specific rooting distributions that are fixed throughout the simulation. Transpiration from potential (non-water limited) stomatal conductance $\left(g_{s}\right)$ is compared to available soil water supply, with the $c_{\mathrm{i}} / c_{\mathrm{a}}$ ratio (internal leaf to ambient $\mathrm{CO}_{2}$ ratio) adjusted downward to decrease $g_{\mathrm{s}}$ if supply<demand (Haxeltine and Prentice, 1996). The downward adjustment of $g_{\mathrm{s}}$ under drought stress provides a feedback between soil moisture to net photosynthesis, which is recalculated with the drought-stressed $g_{s}$. Temperature can also affect simulated plant vigor in several ways, either indirectly via increasing growing season length, or directly, by affecting the rate of Rubisco activity (Farquhar et al., 1980), or changing plant carbon balance due to changes in autotrophic respiration (Ryan, 1991), or by temperature stress mortality (Sitch et al., 2003).

The first set of simulations with LPJ used observed climate forcing from the CRU TS 3.1 dataset (monthly temperature, precipitation, cloud cover, and number of wet days), atmospheric $\mathrm{CO}_{2}$ concentration data from the Mauna Loa observatory, and soil texture data from FAO (Zobler, 1986), with a fixed soil depth of $1.5 \mathrm{~m}$. A spin-up of 1000 years, recycling the first 30 years of CRU climate data (1901-1930) and pre-industrial $\mathrm{CO}_{2}$ concentrations was carried out to equilibrate vegetation and soil carbon pools. Following the spin-up, a transient simulation with observed climate, simulated fire (but no land use or land-cover change) was implemented through to the year 2009. A second set of climate change simulations were conducted using climate projection data (see Table 2 for list of models) from the Intergovernmental Panel on Climate Change (IPCC) Fourth Assessment Report (AR4-CMIP3) SRES A2 radiative forcing scenario. Climate fields from eleven general circulation models were normalized to the CRU TS 3.1 baseline period of 1961-1990 following methods described by Poulter et al. (2010). These simulations were conducted first with

\section{Table 4}

Summary of the Pearson correlations between the PCA eigenvectors with FPAR (AVHRR-GIMMS) and NPP (LPJ-DGVM) trends. The component with the highest correlation is listed (with the correlation). n.s. (not significant) indicates that the correlations were less than $r<0.15$.

\begin{tabular}{lllll}
\hline Variables & $1982-1990$ & $1991-2000$ & 2001-2010 & $1982-2010$ \\
\hline FPAR DJF & n.s. & n.s. & n.s. & n.s. \\
FPAR MAM & PC1, 0.34 & PC2, 0.27 & PC4, 0.20 & n.s. \\
FPAR JJA & PC1, 0.26 & PC3, -0.18 & PC3, 0.19 & PC2, 0.25 \\
FPAR SON & PC1 \& PC2, 0.33 & PC1, 0.27 & PC3, 0.20 & n.s. \\
NPP DJF & n.s. & n.s. & n.s. & PC2, -0.26 \\
NPP MAM & PC1, 0.21 & PC2, 0.54 & n.s. & PC2, 0.40 \\
NPP JJA & PC2, 0.39 & PC3, 0.66 & PC3, 0.49 & PC2, 0.57 \\
NPP SON & n.s. & PC1, 0.34 & PC3, 0.57 & PC2, 0.29 \\
\hline
\end{tabular}

atmospheric $\mathrm{CO}_{2}$ increasing according to the SRES A2 storyline and a second time with atmospheric $\mathrm{CO}_{2}$ held constant to pre-industrial concentrations ( $270 \mathrm{ppm}$ ) to evaluate the model sensitivity to $\mathrm{CO}_{2}$ fertilization.

\subsection{Model benchmarking}

Simulated net primary production (the summed annual increment of wood, root and foliage production) was evaluated with data from a forest plot network (Luo, 1996) and an independent remote-sensing product (Zhao and Running, 2010). The forest plot database was selected because of the relatively high density of observations within the study area compared to other global NPP databases (Luyssaert et al., 2007; Vicca et al., 2012). Uncertainties in the forest plot database were not available and so additional estimates of satellite-derived NPP from MODIS Product 17, Collection 5.1, were evaluated. The forest plot dataset included forest age, and plots younger than 75 years old were removed so that the comparison with LPJ quasi-steady state simulations was not confounded by age-productivity constraints. For each forest plot, the climate data (mean annual temperature and annual precipitation) were available. The plot climate data were compared with the CRU climatology used to run LPJ and plots where temperature differences were greater than $2.5^{\circ} \mathrm{C}$ and precipitation differences were greater than $250 \mathrm{~mm} \mathrm{yr}^{-1}$ were removed from the analysis. Annual NPP from MODIS was averaged over the 2000-2006-time period at $1 \mathrm{~km}$ spatial resolution. MODIS NPP is estimated using the Biome-BGC carbon cycle model that is driven by surface reflectance data that are converted to FPAR. As such, MODIS NPP is not a data product, but is useful as an independent model-data evaluation tool. Gridded $1 \mathrm{~km}$ climate fields of mean annual temperature and precipitation from the WorldClim database (Hijmans et al., 2005) were compared with the CRU climate dataset used for LPJ and a filter developed to remove grid cells where temperature and precipitation were significantly different from the forcing data used for LPJ.

\subsection{Agreement in climate sensitivity among data sources}

The overlapping time series from AVHRR-FPAR, annual tree growth, and simulated NPP from the LPJ model were compared to one another to determine similarities in interannual variability. To compare with tree ring data, Pearson correlation coefficients were estimated to evaluate the relationship between FPAR and NPP anomalies, calculated for each of the four seasons, with the annual 

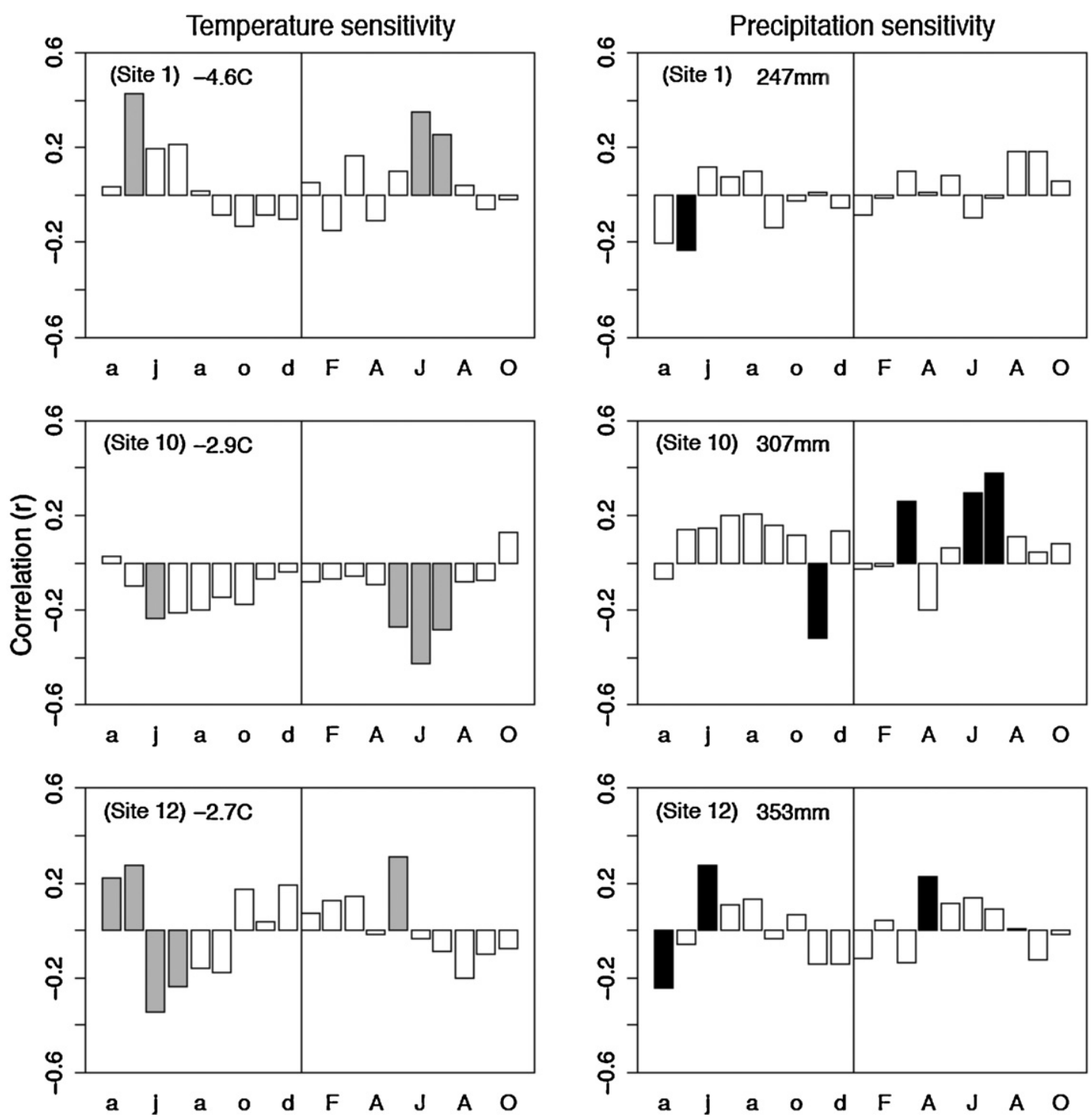

\section{Month}

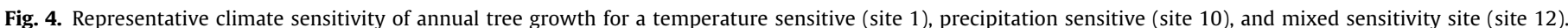

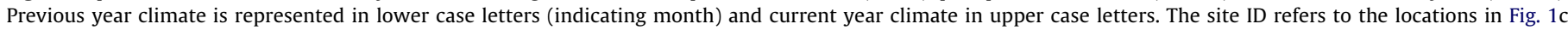

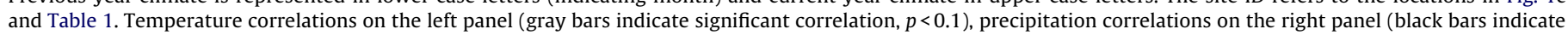
significant correlation, $p<0.1$ ).

anomalies of the tree ring data. The significance of the correlation was compared to an alpha value of 0.1 .

\section{Results}

\subsection{Regional trends in greening and climate}

Between 1982 and 2010, spring and summer seasonal FPAR (MAM, JJA) showed a greening trend in $6.2-7.5 \%$ of the region, a browning trend in $2.6-3.9 \%$ of the region, and non-significant $(p>0.1)$ trends in the remainder of the study area (Fig. 2a). Much of the long-term greening trend was found outside of Inner Mongolia in the southern or northern portions of Inner Asia, with the browning trend more prominent in central Mongolia in JJA and SON (Fig. 2a). The magnitude of the long-term greening FPAR trends was relatively small $\left(\sim 0.001-0.002\right.$ units $\left.\mathrm{yr}^{-1}\right)$ compared to the decadal trends, which also exhibited spatially variable hotspots of greening and browning between each decade. For example, MAM and JJA greening trends were largest between 1982 and 1990 (7.2-8.5\% of region greened, $\left.\sim 0.007-0.009 \mathrm{yr}^{-1}\right)$, declining slightly in 1991-2000 (5.0-7.4\%, 0.006-0.007 $\left.\mathrm{yr}^{-1}\right)$, and again for the 2001-2010 period $\left(4.4-7.8 \%, \sim 0.006-0.009 \mathrm{yr}^{-1}\right)$. Over the same decadal periods, the area and rate of browning tended to increase, from $1.6-2.7 \%$ (1982-1990) to $2.7-5.1 \%$ (1991-2000), to $2.2-5.6 \%$ (2001-2010), with the change in FPAR browning increasing from 0.002 to $0.007 \mathrm{yr}^{-1}$.

The difference between the decadal and the 30-year trends appears to be driven by short-term climate variation followed by rapid ecosystem recovery versus longer-term climate change and ecosystem response. For example, the 30-year change in annual air temperature of $0.04{ }^{\circ} \mathrm{Cyr}^{-1}$ masks large seasonal and inter-decadal variability (Fig. 2b). Long-term (1982-2009) MAM $\left(0.076{ }^{\circ} \mathrm{Cyr}^{-1}\right)$ and $\mathrm{JJA}\left(0.059{ }^{\circ} \mathrm{Cyr}^{-1}\right)$ warming was larger than the mean annual trend. Decadal trends for MAM and JJA were 

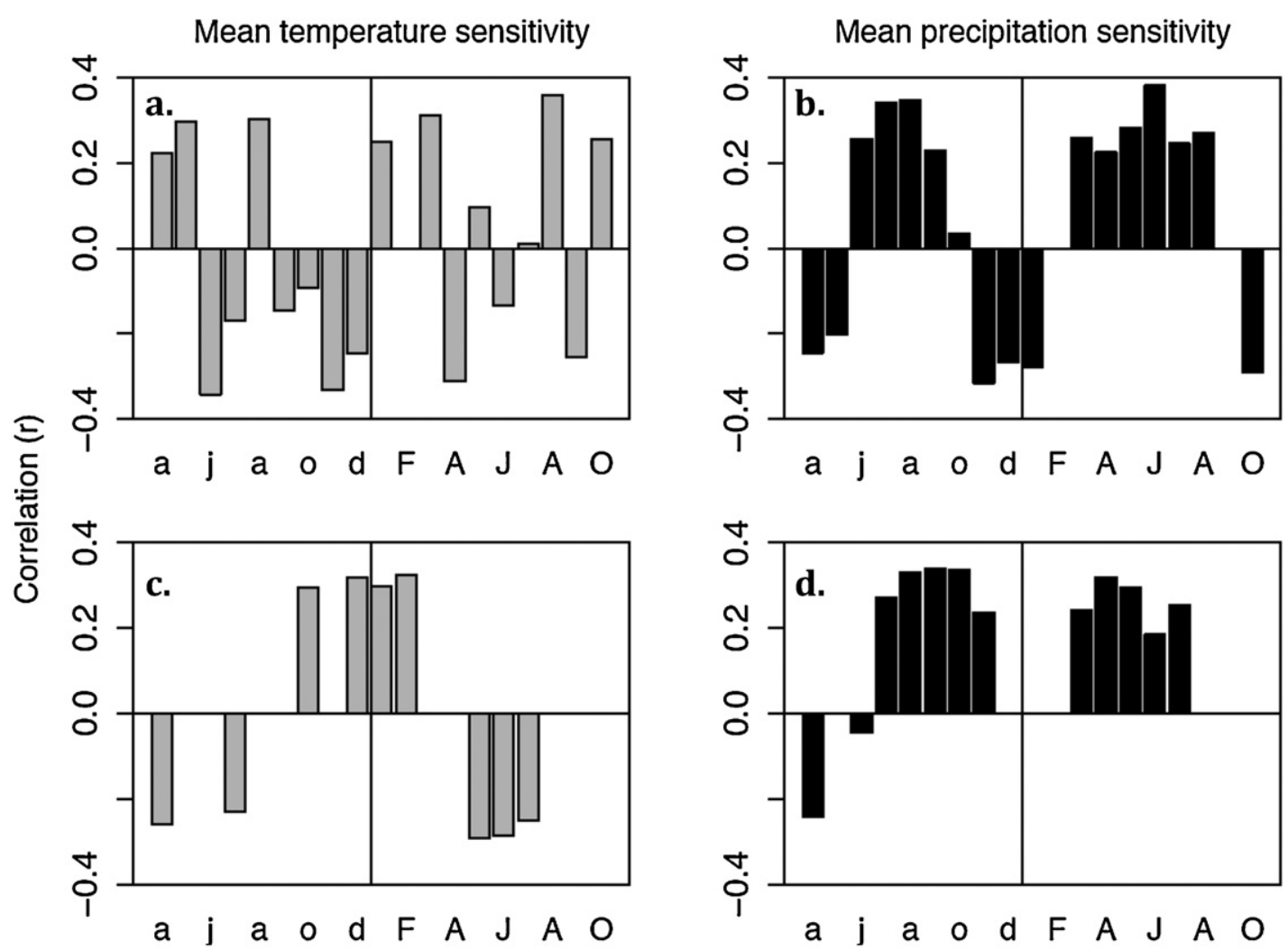

Month

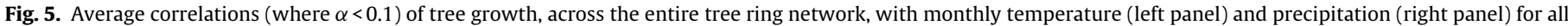

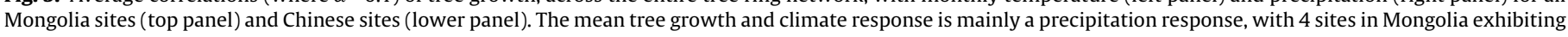
a temperature response (see Table 5).

as high as $0.15^{\circ} \mathrm{Cyr}^{-1}$ and $0.12{ }^{\circ} \mathrm{Cyr}^{-1}$ in $1991-2000$. Trends in precipitation showed similar seasonal and inter-decadal variability as temperature (Fig. 2c). A long-term decreasing precipitation trend of $-0.07 \mathrm{~mm} \mathrm{yr}^{-1}$, was observed, mainly related to a decrease in JJA rainfall $\left(-0.25 \mathrm{~mm} \mathrm{yr}^{-1}\right)$. However, JJA precipitation patterns fluctuated noticeably on decadal scales (and spatially), at the regional scale, ranging from $+0.46 \mathrm{~mm} \mathrm{yr}^{-1}(1982-1990)$ to $-0.48 \mathrm{~mm} \mathrm{yr}^{-1}$ (1991-2000) and $+0.49 \mathrm{~mm} \mathrm{yr}^{-1}(2001-2010)$.

\section{Table 5}

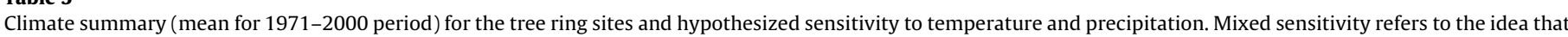
either precipitation or temperature constrains tree growth from year-to-year. These sites are likely to be more representative of non-treeline or forest border sites.

\begin{tabular}{|c|c|c|c|}
\hline Site ID (Fig. 1c and Table 1) & Mean annual temperature $\left({ }^{\circ} \mathrm{C}\right)$ & Mean annual precipitation $\left(\mathrm{mm} \mathrm{yr}^{-1}\right)$ & Dominant climate sensitivity \\
\hline a & 8.2 & 703.3 & Precipitation \\
\hline b & 11.5 & 518.8 & Precipitation \\
\hline c & 4.4 & 452.5 & Precipitation \\
\hline d & 8.0 & 362.7 & Precipitation \\
\hline $\mathrm{e}$ & 5.9 & 367.4 & Precipitation \\
\hline $\mathrm{f}$ & 7.6 & 271.8 & Precipitation \\
\hline $\mathrm{g}$ & 5.6 & 315.9 & Precipitation \\
\hline $\mathrm{h}$ & 2.2 & 320.8 & Precipitation \\
\hline i & 1.9 & 308.6 & Precipitation \\
\hline 1 & -4.6 & 246.6 & Temperature \\
\hline 2 & 0.7 & 363.5 & Precipitation \\
\hline 3 & -0.3 & 353.5 & Precipitation \\
\hline 4 & -4.6 & 344.3 & Mixed \\
\hline 5 & -6.1 & 282.3 & Temperature \\
\hline 6 & -9.1 & 343.2 & Temperature \\
\hline 7 & -6.0 & 280.5 & Precipitation \\
\hline 8 & -1.0 & 290.3 & Precipitation \\
\hline 9 & -1.6 & 335.3 & Precipitation \\
\hline 10 & -2.8 & 306.8 & Precipitation \\
\hline 11 & 0.7 & 363.5 & Precipitation \\
\hline 12 & -2.7 & 352.6 & Mixed \\
\hline 13 & -7.1 & 264.5 & Temperature \\
\hline 14 & -1.9 & 377.3 & Precipitation \\
\hline 15 & -2.1 & 332.7 & Mixed \\
\hline 16 & -1.9 & 277.3 & Precipitation \\
\hline
\end{tabular}


The dominant spatial features of climate trends in the 1982-2009-time period were captured by PCA (Fig. 3), with the negative eigenvalues associated with PC1 combined with negative temperature loadings (Table 3 ) indicating the region where warming trends are predominant. The spatial pattern of positive eigenvalues for PC2 (with negative loadings for precipitation) indicates regions where summer drying trends are important and spatially coherent with JJA drying (over 1982-2010), whereas PC3 negative eigenvalues indicate a weaker MAM increase in precipitation (positive MAM loadings). However, the low correlation between the PCA loadings and trends in FPAR suggest that processes beyond the direct influence of climate (i.e., possibly interactions with land use) are playing a role on vegetation greening and browning.

The PCA loadings (Table 3 ) were also found to be sensitive to the time period that the climate trends represented. In general, DJF temperature trends and MAM precipitation trends were most important for the decadal climate trend loadings. In comparison, over the longer time period, MAM temperature trends and MAM and JJA precipitation trends had the highest loadings for the 1982-2010-time period. Correlations between the first three components and the seasonal FPAR trends (Table 4) suggest (1) that only growing season FPAR trends (MAM and JJA, and occasionally, SON) are related to climate variability and (2) that decadal correlations with climate are driven mainly by temperature $(r=0.19-0.34$, $p<0.1$ ), whereas the long-term trend in growing season FPAR is determined by long-term trends in JJA precipitation $(r=0.25$, $p<0.1$ ).

\subsection{Climate sensitivity of tree growth and AVHRR-FPAR}

The tree ring collection sites were grouped a priori into three categories defined by hypothesized tree-growth sensitivity to climate regime (i.e., precipitation, temperature, or mixed; Fig. 4 and Table 1). For example, expected drought-sensitive trees were collected at the forest-steppe/grassland or lower forest border. Temperature-sensitive sites were collected at the upper forest or mountain-top tree line. Trees with mixed climatic sensitivity (i.e., no single climatic factor dominates annual radial increment) were collected from the forest interior and not at expected drought or temperature sensitive locations.

For data interpretation, precipitation sensitive sites were characterized by positive correlations between tree growth and precipitation and negative correlations between tree growth and temperature during the growing season. Temperature sensitive sites were characterized by positive temperature and tree growth correlations in the growing season. Mixed climate sensitivity sites had positive correlations for both temperature and for precipitation with tree growth. As hypothesized in Table 1, out of the 16 sites in Mongolia (Fig. 5a and b) nine were mainly precipitation sensitive $(2,3,7,8,9,10,11,14,16)$, four were temperature sensitive sites $(1,5,6,13)$, and three were mixed sensitivity sites $(4,12,15)$. In comparison, all nine sites in China were precipitation sensitive (Fig. $5 \mathrm{c}$ and d). June and July precipitation and temperature tended to have the highest correlation with tree growth; winter precipitation was not well correlated for most of the sites (most likely because winter precipitation is very low), but previous year summer climate (both precipitation and temperature) showed similarly high correlations to current year (Fig. 5).

Compared to the seasonal AVHRR time series data, JJA-FPAR correlations with annual tree growth were highest in Mongolia (ranging from 0.13 to $0.7, p<0.1$ ), and MAM-FPAR correlations were highest in China (Fig. 6). These correlations confirm that for the Chinese sites, tree growth is optimized in the cooler spring season when atmospheric water demand is lower, whereas in Mongolia, tree growth is driven by the JJA season. The lowest AVHRR-FPAR

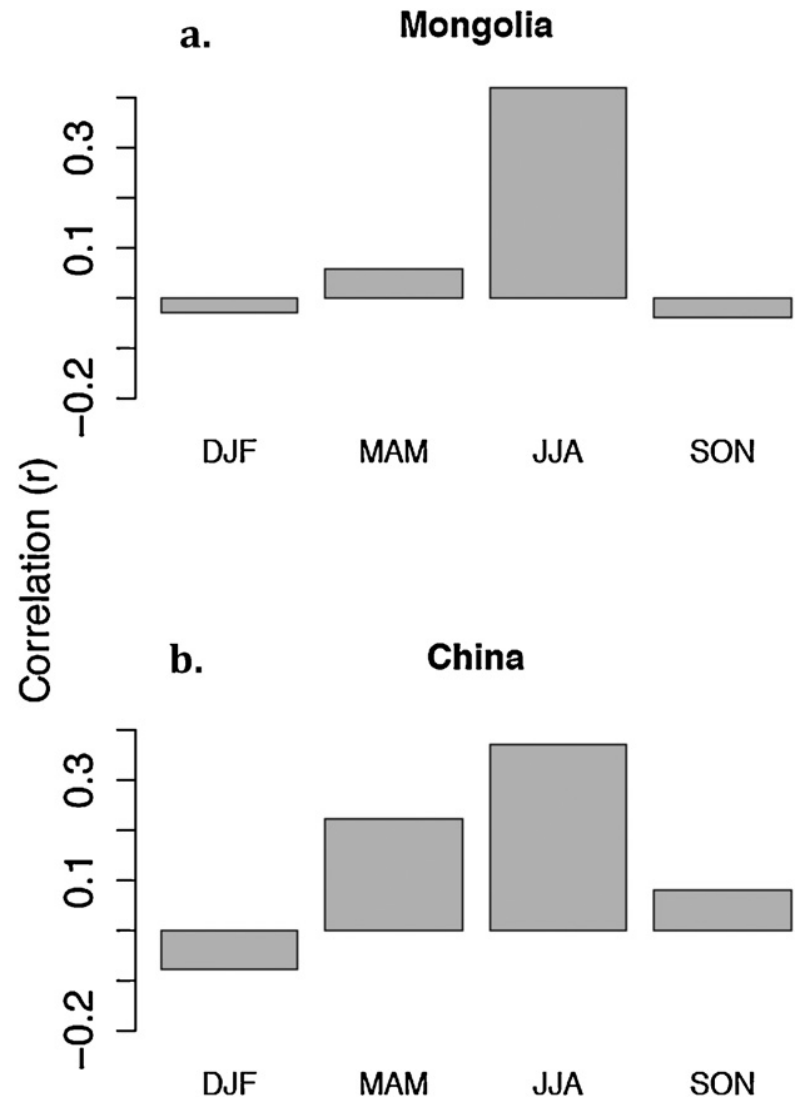

Fig. 6. Mean correlations across all tree ring sites between annual tree growth anomalies and seasonal AVHRR-FPAR anomalies from correlations between time series from 1982 to 2010 . For Mongolia, tree growth correlated most strongly with JJA-FPAR, whereas for China, the correlation was also high in the MAM season.

and tree ring correlations were at sites 6 and 13, which were temperature sensitive sites (Table 5), and at sites 4 and 15, which were mixed-climate sensitive sites (Table 5). These same sites also displayed much lower inter-annual variability in tree growth that was inconsistent with large inter-annual variability in the AVHRR-FPAR data. It is possible that for these sites, the tree ring collections were not representative of the AVHRR-averaging window of $8-\mathrm{km}$, or that dampened inter-annual variability in radial growth was too weak of a signal to be measured by AVHRR.

For the AVHRR-FPAR climate sensitivities, the mean site response for both Mongolia and China showed negative correlations with growing season air temperature and positive correlations with growing season precipitation-indicating precipitation as the main control on AVHRR-FPAR. However, in contrast to the tree ring and model correlations, AVHRR-FPAR did not have as clear patterns in precipitation correlations, with late growing season precipitation (months 6 and later) and AVHRR-FPAR correlations insignificant.

\subsection{Model benchmarking and climate sensitivity of LPJ}

Across the forest validation plot database, annual NPP (filtered by climate correspondence between observed and modeled) was estimated at $475.6 \pm 158.9 \mathrm{gC} \mathrm{m}^{-2}$ for the plot database, $390.6 \pm 85.2 \mathrm{gC} \mathrm{m}^{-2}$ for MODIS, compared to $521.2 \pm 79.3 \mathrm{gC} \mathrm{m}^{-2}$ for LPJ, with the uncertainty representing spatial heterogeneity. At the regional level, MODIS was statistically different to the observations (2-sided $t$-test, $p=0.01$ ), but for LPJ and the plot-level NPP comparison, the NPP estimates were statistically similar (2-sided t-test, $p>0.1$ ). At the plot level, however, correlations between 

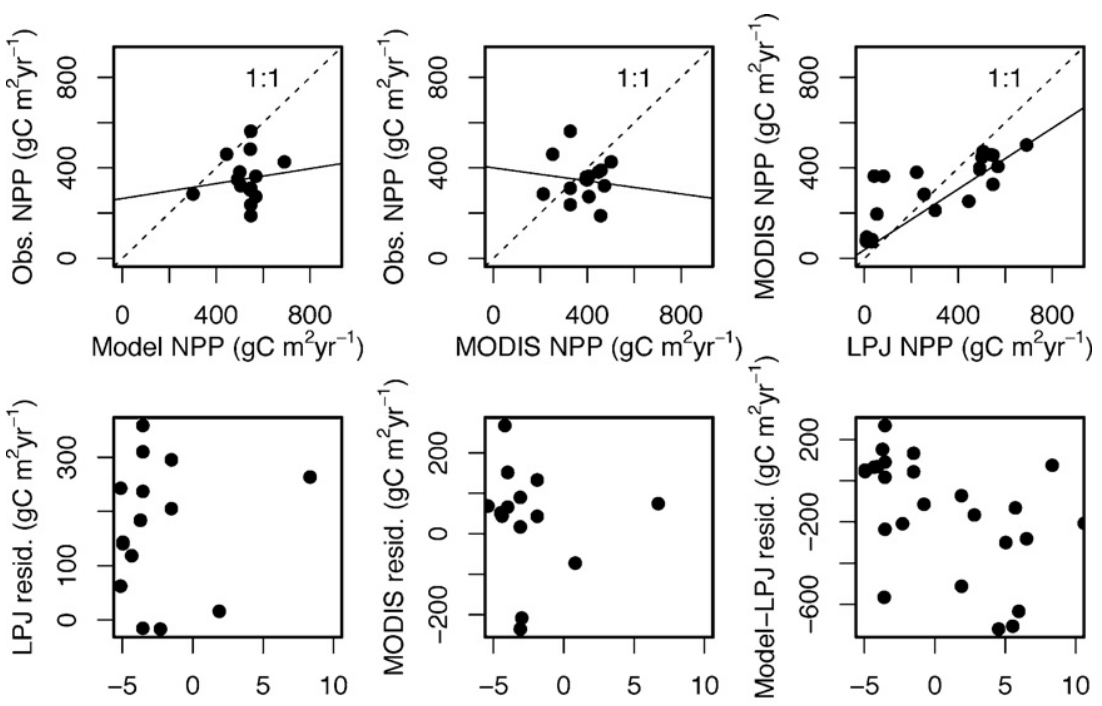

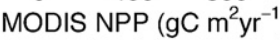

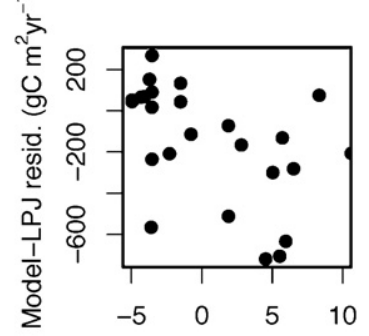

Air temperature $\left({ }^{\circ} \mathrm{C}\right)$

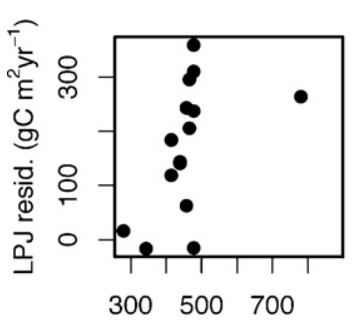

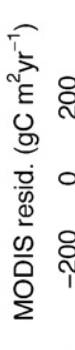

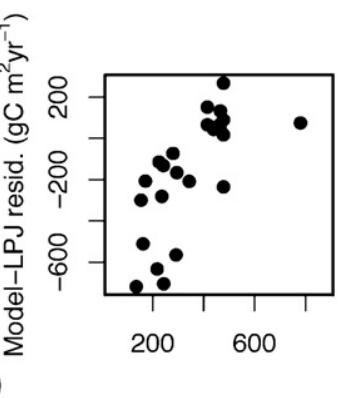

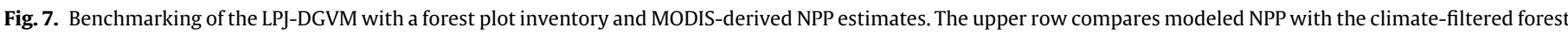

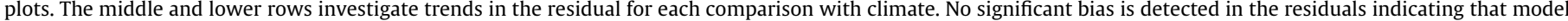
performance with the data benchmark is affected mainly by random errors.

modeled and observed annual NPP (Fig. 7, upper row) were not significant for either LPJ or MODIS linear regressions with plot NPP $(p>0.1)$. In contrast, LPJ and MODIS NPP were significantly correlated with one another $\left(p<0.05, R^{2}=0.39\right)$. The agreement between models suggests that the observed NPP data may have high uncertainties preventing a close model-data agreement or that the patchy distribution of forest stands is problematic in comparison to the grain (grid cell size) of the remote sensing and modeling data. This conclusion is partially supported by an analysis of the model-data residuals (Fig. 7, middle and lower rows) that do not show significant correlations with temperature or precipitation and indicate no particular model bias across the study region but rather random errors resulting from benchmarking data sources.

The LPJ simulations resulted in a present-day PFT distribution dominated by boreal needleleaf evergreen and a smaller fraction of boreal broadleaf summergreen trees and C3 (photosynthetic pathway) grasses. Within the LPJ DGVM framework, boreal PFTs have an optimal daily temperature for photosynthesis ranging from 10 to $15^{\circ} \mathrm{C}$ and are able to establish in climate zones where 20-year running mean monthly temperature is $<2{ }^{\circ} \mathrm{C}$. Trends in seasonal modeled NPP showed remarkably similar correlations with the climate PCA eigenvectors to those of AVHRR-FPAR, but with some notable differences (Table 3). For example, the LPJ-NPP correlations with the climate PCA components tended to be larger than the AVHRR-FPAR correlations, which is partly due to do the CRU data being used as the climate forcing, but could also indicate a larger model NPP sensitivity to climate than the FPAR sensitivity to climate or the importance of non-climatic factors on AVHRRFPAR variability. In principle, FPAR is linearly related with NPP
(Potter et al., 2003), and while a similar directional response for AVHRR-FPAR and LPJ-NPP to climate would be expected, differences in their sensitivity to climate might also be arise. For the 1982-2010 period, the seasonal NPP trends correlated highest with PC2, indicating that negative trends in winter, spring and summer precipitation were having a large effect on simulated annual NPP. PC1, which had high loadings for all seasonal temperature trends, was not highly correlated with any of the seasonal LPJ-NPP trends during 1982-2010, indicating low model sensitivity to temperature relative to precipitation.

Compared to the climate sensitivity of representative tree-ring sites (Fig. 4), the LPJ annual NPP sensitivity to precipitation was also much higher, causing all sites (except site 6 , which was temperature sensitive for simulated LPJ-NPP) to be precipitation sensitive for LPJ-NPP. The precipitation sensitivity of LPJ modeled NPP is clearly shown by the positive correlations between growing season precipitation and NPP and negative correlations with growing season temperature and NPP for both Mongolia and China (Fig. 8). These modeling results contrast with more mixed climate sensitivity of the Mongolian tree ring sites (Fig. 5). Interestingly, a positive temperature correlation with autumn temperature (September and October) and NPP was observed for the Mongolian and Chinese sites (Fig. 9), suggesting that the equations governing NPP in LPJ are responding to temperature trends by possibly increasing growing season length.

Correlations between the time series of seasonal modeled-NPP and annual tree growth also indicated highest correlations in the JJA season for Mongolia (similar with AVHRR-FPAR and tree ring correlations) and ranged from 0.31 to 0.62 . The lowest model-data correlations were found for the mixed climate and temperature 
Temperature sensitivity

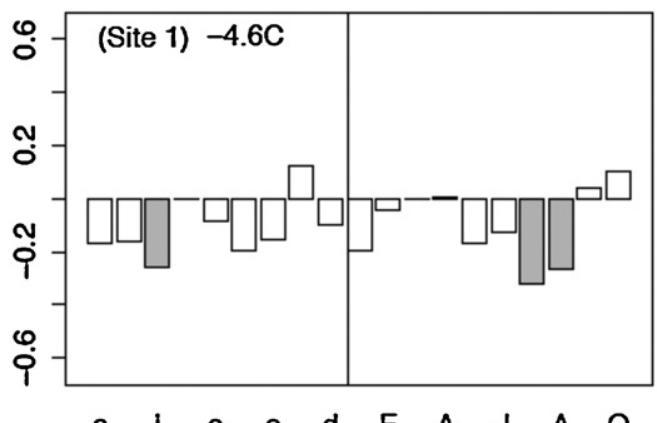

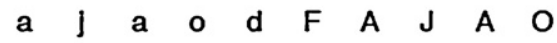
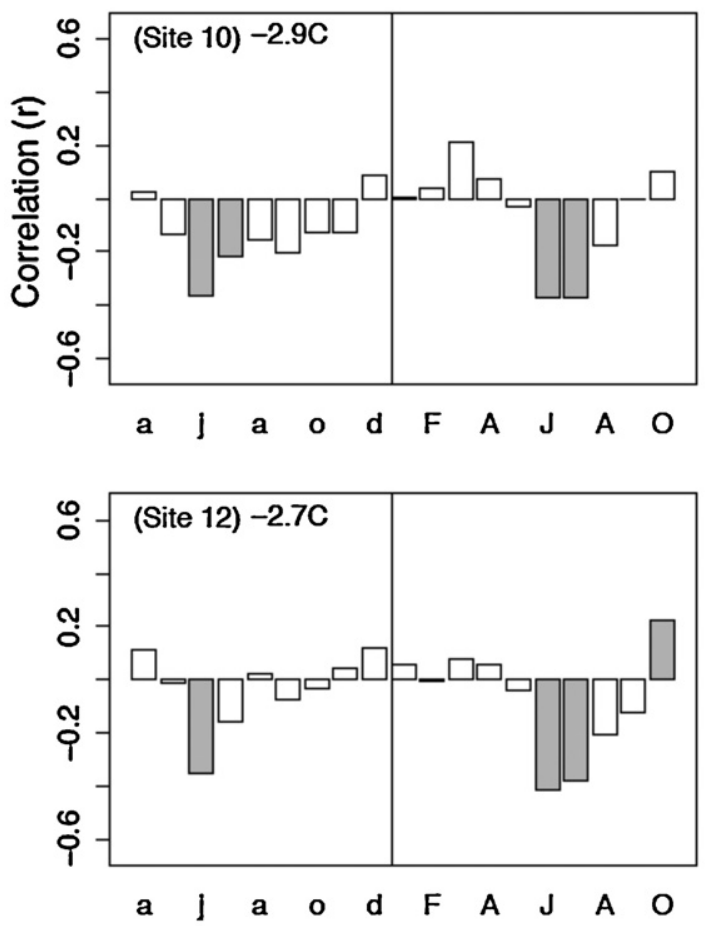

Precipitation sensitivity
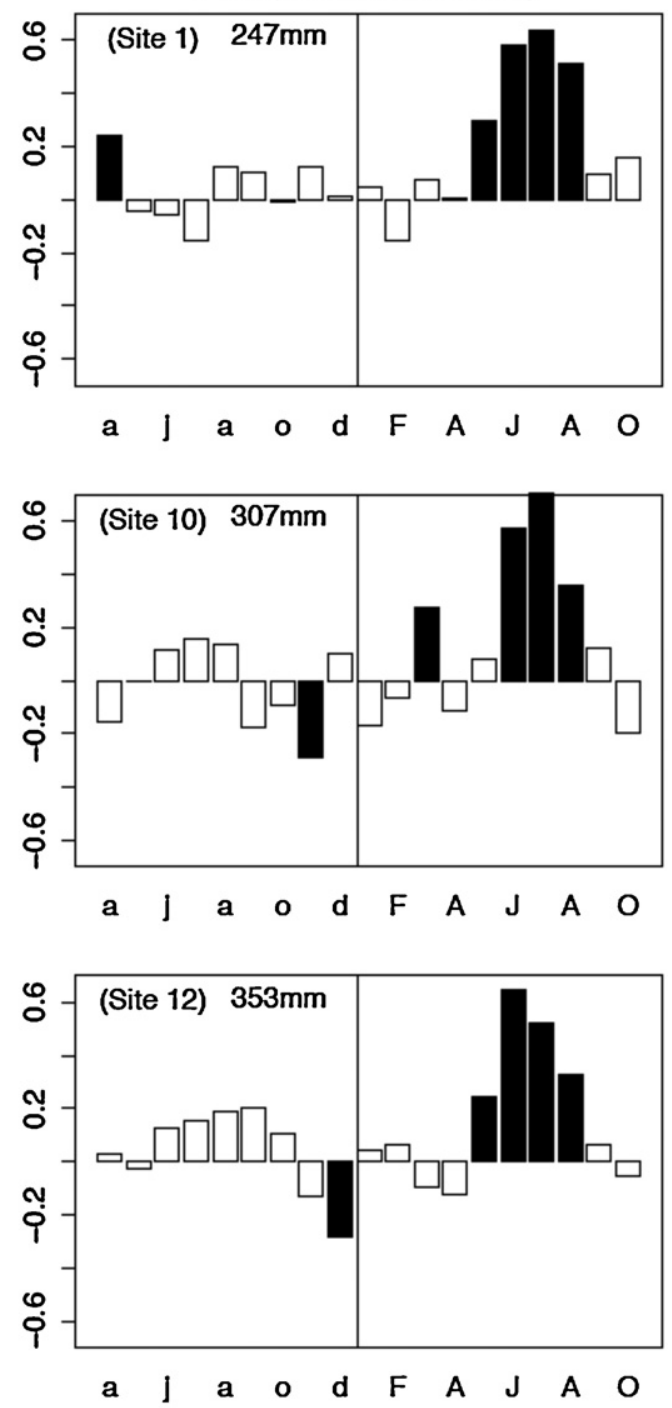

Month

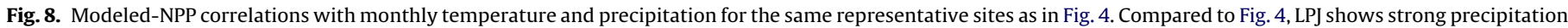
sensitivity (or bias) for all three sites, including the temperature (site 1) and the mixed (site 12) sensitivity sites.

sensitive sites. For China, the higher correlations were also shifted to the MAM period, as was observed with the AVHRR-FPAR and tree ring correlations and ranged from 0.23 to 0.43 for the March-May growing season in China.

\subsection{Climate projections}

Average simulated regional NPP for 1991-2000 was $281.7 \mathrm{~g} \mathrm{C} \mathrm{m}^{-2} \mathrm{yr}^{-1}\left( \pm 10.8 \mathrm{~g} \mathrm{C} \mathrm{m}^{-2} \mathrm{yr}^{-1}\right)$ for the $11 \mathrm{GCM}$ models. By 2100 (referring to an averaging period 2091-2098), NPP had increased by $35-80 \%$ for all climate projections, with increasing $\mathrm{CO}_{2}$, to $454.8 \mathrm{~g} \mathrm{C} \mathrm{m}^{-2} \mathrm{yr}^{-1}\left( \pm 38.8 \mathrm{~g} \mathrm{C} \mathrm{m}^{-2} \mathrm{yr}^{-1}\right)$. In the absence of a $\mathrm{CO}_{2}$ fertilization effect on photosynthesis and water-use efficiency since the industrial revolution, 1991-2000 NPP was $234.4 \mathrm{~g} \mathrm{C} \mathrm{m}^{-2} \mathrm{yr}^{-1}\left( \pm 10.7 \mathrm{~g} \mathrm{C} \mathrm{m}^{-2} \mathrm{yr}^{-1}\right)$, and decreased to $209.7 \mathrm{~g} \mathrm{C} \mathrm{m}^{-2} \mathrm{yr}^{-1}\left( \pm 10.8 \mathrm{~g} \mathrm{C} \mathrm{m}^{-2} \mathrm{yr}^{-1}\right)$ by 2100 (up to a $28 \%$ decrease, but with two models showing a $\sim 5 \%$ increase. These models were the NCAR-CCSM3 and NCAR-PCM1, which had the highest precipitation increase and lowest temperature change of the 11 GCM projections, respectively (Table 2 ).
The response of NPP to future climate is mainly a question of $\mathrm{CO}_{2}$ fertilization and its direct effect on enhancing photosynthesis, especially in interaction with rising air temperatures, and its indirect effect on water-savings by reducing stomatal conductance relative to carbon uptake (i.e., water-use efficiency). As can be seen in Fig. 10, the rate of increase in NPP between 1901 and 2098 is completely dependent on elevated $\mathrm{CO}_{2}$, with all pre-industrial $\mathrm{CO}_{2}$ climate change scenarios showing deleterious climate effects on plant productivity. The greater difference between the preindustrial and elevated $\mathrm{CO}_{2}$ simulations in the northeastern region of China and parts of northwestern Mongolia suggests a strong influence by temperature change on productivity. In northeast China, increased temperature likely decreases plant productivity through high rates of autotrophic respiration, but in parts of northwestern Mongolia, we simulated a net decrease in tree cover (and FPAR) due to dieback of boreal PFTs and a slow rate of invasion from temperate PFT tree cover (Fig. 10). Fire emissions decreased in the northwestern region of Mongolia where net vegetation cover decreased, but elsewhere, fire emissions increased because of higher fuel loading from increased NPP (Fig. 10). For 
Mean temperature sensitivity

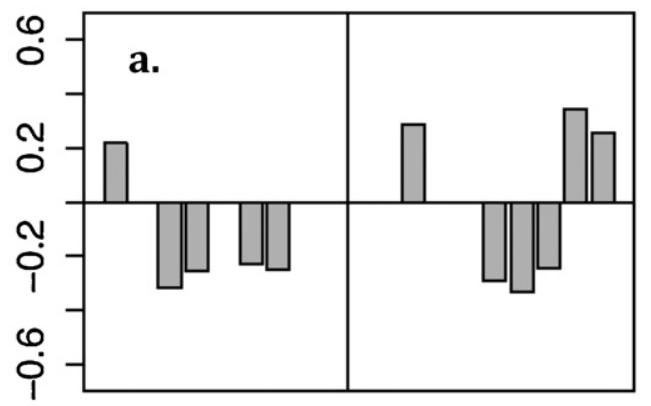

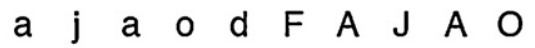

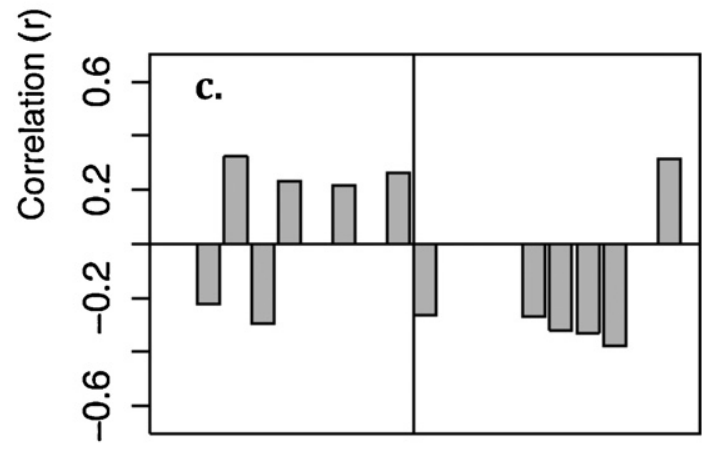

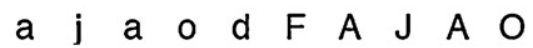

Mean precipitation sensitivity

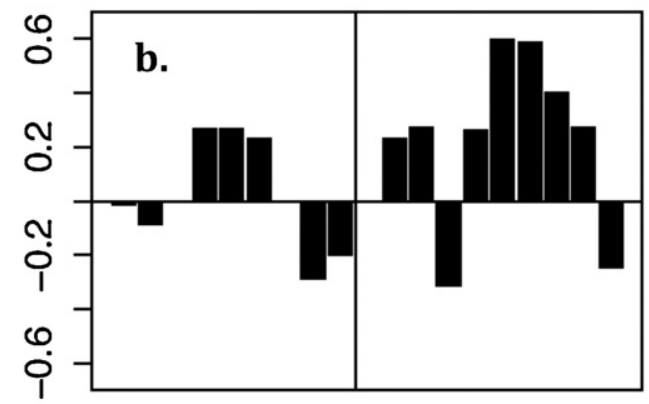

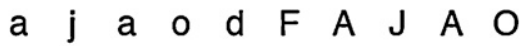

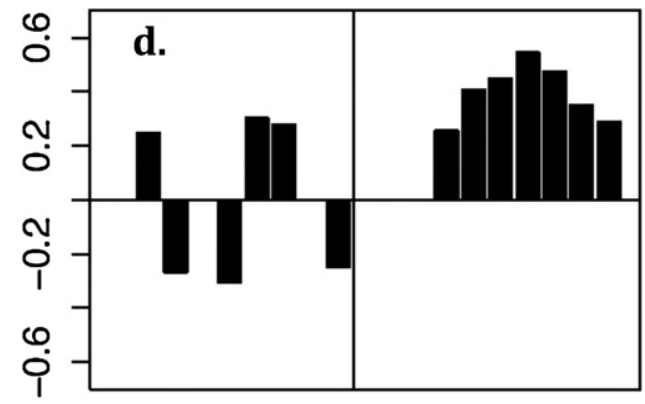

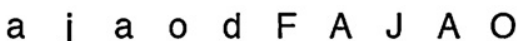

\section{Month}

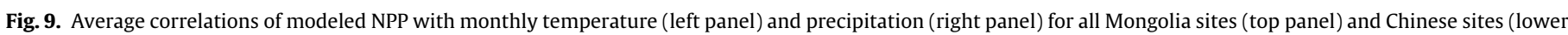

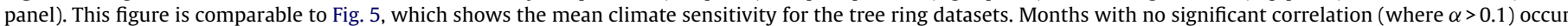
mainly in the non-growing season. The mean NPP and climate response is mainly a precipitation response for both Mongolia and China.

pre-industrial $\mathrm{CO}_{2}$, the modeled trends in fire emissions generally matched those trends for decreasing NPP, with decreasing emissions over most of the region except for some regions of Northern Mongolia.

\section{Discussion}

Throughout Inner Asia, mean annual temperature tends to decrease with increasing latitude and thus changes in air temperature from climate change may be expected to increase ecosystem productivity in predictable ways. However, in semi-arid systems, interactions between precipitation and $\mathrm{CO}_{2}$ may either enhance or dampen these potential warming ecosystem feedbacks. This study confirms that precipitation variability and its trends exert an overwhelming climatic role in determining inter-annual variability in greenness, tree growth, and whole-ecosystem NPP. As expected, the warmer sites in northern China showed strong sensitivity of inter-annual tree growth and of simulated NPP to precipitation. Further, and perhaps more surprisingly, precipitation limitations had an almost equally strong role in the cooler, northern Mongolia sites, with temperature sensitive sites only occurring for 3 locations where mean annual temperature was $<-4.6$ to $-9.1^{\circ} \mathrm{C}$ (Table 5 ). For the original hypothesis, these observations did not strongly support temperature limitation as a control on forest dynamics of the northern arid-steppe vegetation, and rather, precipitation appears to be the dominant control on forest productivity across the entire region.

Trends in AVHRR-FPAR revealed large inter-decadal variability, as observed by previous work in Inner Asia (Piao et al., 2005; Potter et al., 2007). However, from decade to decade, the areal extent of greening consistently decreased, with an almost equal increase in the area showing browning trends. While the interdecadal trends were more closely correlated with temperature, the long-term FPAR trend was more influenced by a drying signal, especially during the JJA season. This provides further evidence for the effect on vegetation activity of a long-term drying trend over the region, which has been observed in recent forest mortality events and other climatological records (Davi et al., 2013; Pederson et al., 2013). In addition, the AVHRR-FPAR data helped confirm the dominant seasonal climate response of annual tree growth to JJA precipitation. Changes in land use, and in particular, grazing intensity, are known to exacerbate grassland deterioration during drought (Orlovsky et al., 2011). Part of the local browning trends may partly be driven by this interaction and might explain why the correlations between climate and FPAR trends only explained a small fraction of the total variance. Alternatively, the pronounced MAM greening may also initiate lagged vegetationatmosphere feedbacks by causing soil moisture to be depleted earlier each year and to cause surface warming due to a reduction in latent energy fluxes later in the growing season. Regarding our second hypothesis, this study confirms that the monthly climate sensitivity of tree growth (JJA) is also found in the seasonal FPAR variability (JJA). This indicates that changes in summer climate may be disproportionately more important for tree growth than elongation of growing season (Kaufmann et al., 2004, 2008), and that lag effects (i.e., previous year climate conditions) and effects on non-structural carbohydrate reserves may be less significant in this region.

In general, the LPJ DGVM showed higher interannual sensitivity of NPP to precipitation than FPAR and annual tree growth. This 


\section{$\Delta \mathrm{NPP}\left(\mathrm{gC} \mathrm{m}^{2} \mathrm{yr}^{-1}\right) \quad \Delta$ Tree cover $\left(\mathrm{yr}^{-1}\right)$}

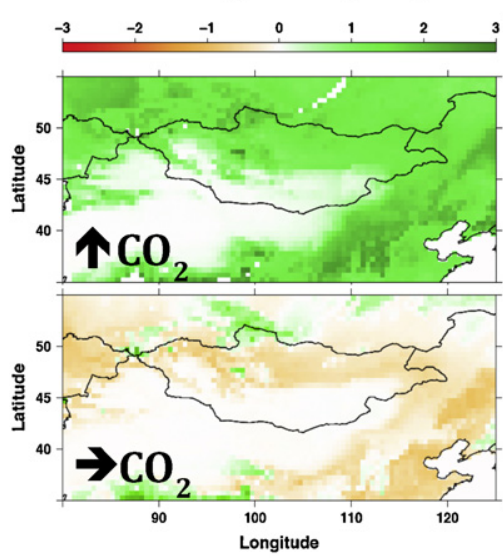

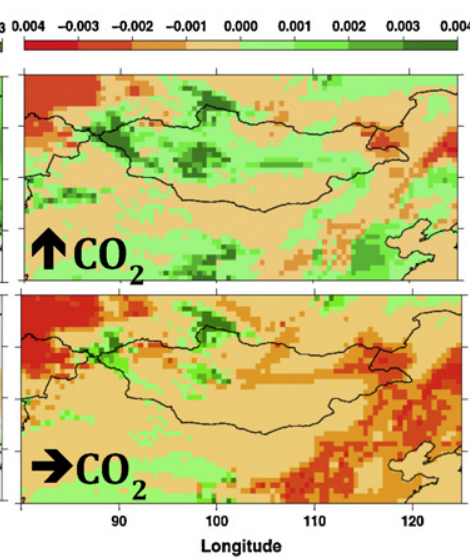

$\Delta$ Fire $\left(\mathrm{gC} \mathrm{m}^{2} \mathrm{yr}^{-1}\right)$

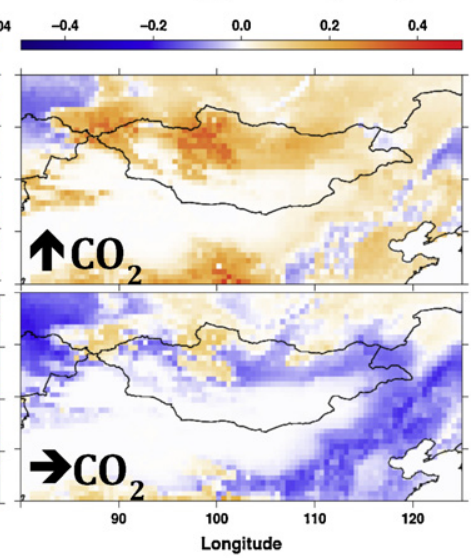

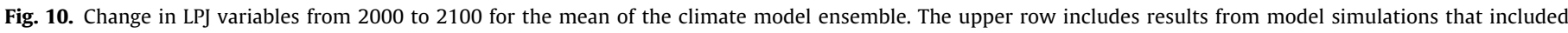

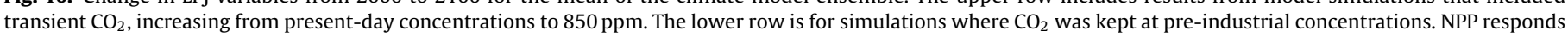

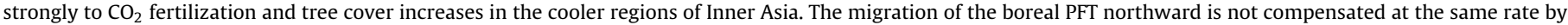
invasion of temperate PFTs, resulting in a net decrease of tree cover. Fire emissions respond to changes in climate and in fuel loading, which is determined by NPP.

pattern of high inter-annual model sensitivity to climate has also been shown in a European tree ring network (Babst et al., 2012), and may be due partly to confounding effects of using the same climate forcing data in correlations with model output (i.e., NPP). However, the high model sensitivity also indicates that the model processes related to soil moisture availability (i.e., soil texture, depth, water holding capacity), or to the physical transport of water from roots to leaves (wood anatomy and cavitation response) need to be evaluated with observational or experimental data. Because many of the tree ring collections were developed specifically to reconstruct hydroclimatic variation, scaling the site level climate sensitivity to the region should be made with caution. However, the model sensitivities consistently show higher precipitation correlations compared to tree ring data, suggesting a particular model bias in this region compared to observations.

Consistent with the third hypothesis, the future of Inner Asian ecosystems is highly dependent on $\mathrm{CO}_{2}$ feedbacks on productivity and water-use efficiency (this study; Notaro et al., 2005). The $\mathrm{CO}_{2}$ photosynthesis feedback is especially important as air temperature increases because elevated $\mathrm{CO}_{2}$ reduces temperature-dependent photorespiration (Hickler et al., 2008). Because there have been so few $\mathrm{CO}_{2}$ experiments on intact ecosystems, and most of the experiments have taken place in temperate ecosystems (Norby et al., 2005), it is not possible to fully evaluate model responses outside of temperate regions (Hickler et al., 2008). The strong compensatory effect of $\mathrm{CO}_{2}$ fertilization to counter carbon losses from forest dieback or water stress has also been shown in simulations of climate change impacts in tropical systems (Poulter et al., 2010). Compared to observations of tree growth, a global signal for $\mathrm{CO}_{2}$ effects on tree growth appears to be relatively mixed (Brienen et al., 2012; Gedalof and Berg, 2010). Carbon isotope studies do suggest that increases in water-use efficiency at the tree level have occurred over the 20th century, but water losses related to increases in growing season length may have negated any net water savings at the ecosystem scale. In addition, forest growth in northern latitudes tends to show decreasing sensitivity to temperature variability (i.e., 'divergence'). Divergence has been observed across a range of boreal ecosystems (D’Arrigo et al., 2007), suggesting an increasing importance of water-limitation (Williams et al., 2011) and perhaps evidence for a weak direct and indirect $\mathrm{CO}_{2}$ effect of forest productivity.

Because the climate projections mainly show increases in precipitation (Table 2 ), the direct climate impact on modeled ecosystem dynamics is most likely related to temperature effects causing increased respiration and decreased Rubisco activity (although atmospheric increases in water demand due to greater vapor pressure deficit would have also altered the difference between water supply and demand). This was reflected in the net effect of vegetation mortality and migration in northwestern Inner Asia, also influenced the spatial pattern of changes in NPP under climate change. Mortality in the LPJ-DGVM occurs from carbon starvation (i.e., when autotrophic respiration exceeds carbon uptake), when temperature thresholds for establishment are exceeded, or due to mortality related to fire. Simulated mortality may be relatively abrupt because genetic or enzymatic adaptation warmer temperatures is not represented. On the other hand, the effects of drought stress on xylem cavitation (embolisms due to high tension from large soil to atmosphere water gradients) are not accounted for in LPJ (McDowell et al., 2011). Contrary to the third hypothesis, increases in temperature in the northern region caused decreases in NPP on the trailing edge of the boreal PFT distribution, resulting in a net decrease of forest cover because the migration of temperate PFTs to fill these gaps took place too slowly.

\section{Conclusion}

Ecosystem dynamics in cold climate zones have been considered primarily temperature sensitive (Nemani et al., 2003). For example, inter-annual boreal forest productivity has been used as a basis for tree-ring based temperature reconstruction from trees at the forest-tundra ecotone (D'Arrigo et al., 2000). From a climate change perspective, this suggests that cool climate systems may expand geographically and become more productive due to increased growing season length (Lucht et al., 2002). However, this study shows that attention to precipitation limitations is needed in cool-arid systems when considering inter-annual variability and future climate change impacts. In addition, the role of $\mathrm{CO}_{2}$ fertilization in dry systems suggests that experimental research related to plant productivity and water-use efficiency is required to fully benchmark carbon cycle models.

\section{Acknowledgements}

B. Poulter acknowledges financial support from the Chinese National Natural Science Foundation (NFSC, Grant No. 
31150110145) Young Foreign Scholars program and Peking University, 2011-2012. N. Pederson, C. Leland, R. D’Arrigo and N. Davi acknowledge financial support from the US National Science Foundation funding for DEB-0816700, ATM0117442, OCE0402474 and AGS-PRF1137729. We acknowledge the modelling groups, the Program for Climate Model Diagnosis and Intercomparison (PCMDI) and the WCRP's Working Group on Coupled Modelling (WGCM) for their roles in making available the WCRP CMIP3 multimodel dataset. Support of this dataset is provided by the Office of Science, US Department of Energy. We appreciate the comments from two anonymous reviewers and Susan Moran who helped clarify portions of this article.

\section{References}

Allen, C.D., Macalady, A.K., Chenchouni, H., Bachelet, D., McDowell, N., Vennetier, M., Kitzberger, T., Rigling, A., Breshears, D.D., Hogg, E.H., Gonzalez, P., Fensham, R., Zhang, Z., Castro, J., Demidova, N., Lim, J.H., Allard, G., Running, S.W., Semerci, A., Cobb, N., 2010. A global overview of drought and heat-induced tree mortality reveals emerging climate change risks for forests. For. Ecol. Manage. 259, 660-684.

Babst, F., Poulter, B., Trouet, V., Kun, T., Neuwirth, B., Wilson, R., Carrer, M., Grabner, M., Tegel, W., Levanic, T., Panayotov, M., Urbinati, C., Bouriaud, O., Ciais, P., Frank, D., 2012. Site and species-specific responses of forest growth to climate across the European continent. Global Ecol. Biogeogr., http://dx.doi.org/10.1111/geb.12023.

Brienen, R.J.W., Gloor, M.E., Zuidema, P.A., 2012. Detecting evidence for $\mathrm{CO}_{2}$ fertilization from tree ring studies: the potential role of sampling biases. Global Biogeochem. Cycles 26 (GB1025), http://dx.doi.org/10.1029/2011GB004143.

Cai, Q., Liu, Y., Yang, Y., Shi, J., Sun, J., Wang, L., 2005. Dendrochronological tables and February-March precipitation records in Huanglong, Shaanxi Province, China (in Chinese with English abstract). Mar. Geol. Quatern. Geol. 25, 133-139.

Chen, Z., Sun, Y., He, X., Chen, W., Shao, X., Zhang, H., Wang, Z., Liu, X., 2007. Chinese pine tree ring width chronology and its relations to climatic conditions in Qianshan Mountains (in Chinese with English abstract). Chin. J. Appl. Ecol. 18, 2191-2201.

Cook, E.R., 1985. A Time-Series Analysis Approach to Tree-Ring Standardization. University of Arizona, Tuscon.

Cook, E.R., Anchukaitis, K.J., Buckley, B.M., D’Arrigo, R.D., Jacoby, G.C., Wright, W.E., 2010. Asian monsoon failure and megadrought during the last millennium. Science $328,486-489$.

Cook, E.R., Kairiukstis, L.A., 1990. Methods of Dendrochronology: Applications in the Environmental Sciences. Kluwer, Dordrecht.

D’Arrigo, R., Jacoby, G., Frank, D., Pederson, N., Cook, E., Buckley, B., Nachin, B., Mijiddorj, R., Dugarjav, C., 2001. 1738 years of Mongolian temperature variability inferred from a tree-ring width chronology of Siberian pine. Geophys. Res. Lett. 28 (3), 543-546.

D’Arrigo, R., Jacoby, G., Pederson, N., Frank, D., Buckley, B., Nachin, B., Mijiddorj, R., Dugarjav, C., 2000. Mongolian tree-rings, temperature sensitivity and reconstructions of Northern Hemisphere temperature. The Holocene 10 (6), 669-672.

D'Arrigo, R.D., Wilson, R., Liepert, B., Cherubini, P., 2007. On the 'Divergence Problem' in Northern Forests: a review of the tree-ring evidence and possible causes. Global Planet. Change 60, 289-305.

Davi, N., Pederson, N., Leland, C., Nachin, B., Suran, B., Jacoby, G., 2013. Is eastern MONGOLIA drying? A long-term perspective of a multi-decadal trend. Water Resour. Res., http://dx.doi.org/10.1029/2012WR011834.

Davi, N.K., Jacoby, G., Curtis, A.E., Baatarbileg, N., 2006. Extension of drought records for Central Asia using tree rings: West-Central Mongolia. J. Clim., 288-299.

Farquhar, G.D., von Caemmerer, S., Berry, J.A., 1980. A biochemical model of photosynthetic $\mathrm{CO}_{2}$ assimilation in leaves of $\mathrm{C} 3$ species. Planta 149, 78-90.

Friedman, J.H., 1984. A variable span scatterplot smoother. Laboratory for Computational Statistics.

Gedalof, Z., Berg, A., 2010. Tree-ring evidence for limited direct $\mathrm{CO}_{2}$ fertilization of forests over the 20th Century. Global Biogeochem. Cycles 24 (GB3027), http://dx.doi.org/10.1029/2009GB003699.

Gerten, D., Schaphoff, S., Haberlandt, U., Lucht, W., Sitch, S., 2004. Terrestrial vegetation and water balance - hydrological evaluation of a dynamic global vegetation model. J. Hydrol. 286, 249-270.

Haxeltine, A., Prentice, I.C., 1996. BIOME3: an equilibrium terrestrial biosphere model based on ecophysiological constraints, resource availability, and competition among plant functional types. Global Biogeochem. Cycles 10 (4), 693-709.

Hickler, T., Smith, B., Prentice, I.C., Mjofors, K., Miller, P., Arneth, A., Sykes, M.T., 2008. $\mathrm{CO}_{2}$ fertilization in temperate FACE experiments not representative of boreal and tropical forests. Global Change Biol. 14, 1531-1542.

Hijmans, R.J., Cameron, S.E., Parra, J.L., Jones, P.G., Jarvis, A., 2005. Very high resolution interpolated climate surfaces for global land areas. Int. J. Climatol. 25, 1965-1978.

Jacoby, G., Pederson, N., D’Arrigo, R., 2003. Temperature and precipitation in Mongolia based on dendroclimatic investigations. Chin. Sci. Bull. 48 (14), 1474-1479.
Jeong, S.J., Ho, C.H., Brown, M.E., Kug, J.S., Piao, S.L., 2011. Browning in desert boundaries in Asia in recent decades. J. Geophys. Res.-Atmos. 116 (D02103), http://dx.doi.org/10.1029/2010JD014633.

Kaufmann, R.K., D’Arrigo, R.D., Laskowski, C., Myneni, R.B., Zhou, L., Davi, N.K., 2004 The effect of growing season and summer greenness on northern forests. Geophys. Res. Lett. 31 (L09025), http://dx.doi.org/10.1029/2004GL019608.

Kaufmann, R.K., D’Arrigo, R.D., Paletta, L.F., Tian, H.Q., Jolly, M.W., Myneni, R., 2008 Identifying climatic controls on ring width: the timing of correlations between tree rings and NDVI. Earth Interact. 12,1-14.

Leland, C.W., 2011. Hydroclimatic Variability in North-Central Mongolia as Inferred from Tree Rings. West Virginia University, 84 pp.

Liang, E.Y., Shao, X.M., Liu, H.Y., Eckstein, D., 2007. Tree-ring based PDSI reconstruction since AD 1842 in the Ortindag sand land, east Inner Mongolia (in Chinese with English abstract). Chin. Sci. Bull. 52 (19), 2715-2721.

Liu, Y., Ma, L., 1999. Seasonal precipitation reconstruction during the last 376 years in Hohhot region using tree-ring width (in Chinese with English abstract). Chin. Sci. Bull. 44, 1986-1991.

Lucht, W., Prentice, I.C., Myneni, R.B., Sitch, S., Friedlingstein, P., Cramer, W., Bousquet, P., Buermann, W., Smith, B., 2002. Climatic control of the high-latitude vegetation greening trend and Pinatubo effect. Science 296, 1687-1689.

Luo, T., 1996. Distribution Patterns of Net Primary Productivity for Chinese Major Forest Types and Their Mathematical Models. Chinese Academy of Sciences, Beijing, China.

Luo, Y., Randerson, J.T., Abramowitz, G., Bacour, C., Blyth, E., Carvalhais, N., Ciais, P., Dalmonech, D., Fisher, J.B., Fisher, R., Friedlingstein, P., Hibbard, K., Hoffman, F.M., Huntzinger, D., Jones, C.D., Koven, C., Lawrence, D., Li, D.J., Mahecha, M., Niu, S.L., Norby, R.J., Piao, S.L., Qi, X., Peylin, P., Prentice, I.C., Riley, W.J., Reichstein, M., Schwalm, C.R., Wang, Y.P., Xia, J.Y., Zaehle, S., Zhou, X.H., 2012. A framework for benchmarking land models. Biogeosciences 9, 3857-3874.

Luyssaert, S., Inglima, I., Jung, M., Richardson, A.D., Reichstein, M., Papale, D., Piao S., Schulze, E.D., Wingate, L., Matteucci, G., Aragão, L., Aubinet, M., Beer, C., Bernhofer, C., Black, K.G., Bonal, D., Bonnefond, M., Chambers, J.Q., Ciais, P., Cook, R. Davis, K., Dolman, A.J., Gielen, B., Goulden, M.L., Grace, J., Granier, A., Grelle, A., Griffis, T., Grunwald, T., Guidolotti, G., Hanson, P.J., Harding, R., Hollinger, D.Y., Hutyra, L.R., Kolari, P., Kruijt, B., Kutsch, W., Lagergren, F., Laurila, T., Law, B.E., Le Maire, G., Lindroth, A., Loustau, D., Malhi, Y., Mateus, J., Migliavacca, M., Misson, L., Montagnani, L., Moncrief, J., Moors, E.J., Munger, J.W., Nikinmaa, E., Ollinger, S.V., Pita, G., Rebmanns, C., Roupsard, O., Saigusa, N., Sanz, M.J., Seufert, G., Sierra, C.A., Smith, M.L., Tang, J., Valentini, R., Vesala, T., Janssens, I.A., 2007. $\mathrm{CO}_{2}$ balance of boreal, temperate, and tropical forests derived from a global database. Global Change Biol. 13, 2509-2537.

McDowell, N.G., Beerling, D.J., Breshears, D.D., Fisher, R.A., Raffa, K.F., Stitt, M. 2011. The interdependence of mechanisms underlying climate-driven vegetation mortality. Trends Ecol. Evol. 26 (10), 523-532.

Mitchell, C.D., Jones, P., 2005. An improved method of constructing a database of monthly climate observations and associated high-resolution grids. Int. J. Climatol. 25, 693-712.

Moritz, M.A., Parisien, M.A., Batllori, E., Krawchuck, M.A., van Dorn, J., Ganz, D.J., Hayhoe, K., 2012. Climate change and disruptions to global fire activity. Ecosphere $3(6), 1-22$.

Nemani, R.R., Keeling, C.D., Hashimoto, H., Jolly, W.M., Piper, S.C., Tucker, C.J., Myneni, R.B., Running, S., 2003. Climate-driven increases in global terrestrial net primary production from 1982 to 1999. Science 300 (1560), 1560-1563.

Norby, R.J., DeLucia, E.H., Gielen, B., Calfapietra, C., Giardina, C.P., King, J.S., Ledford, J., McCarthy, H.R., Moore, D.J.P., Ceulemans, R., De Angelis, P., Finzi, A.C. Karnosky, D.F., Kubiske, M.E., Lukac, M., Pregitzer, K., Scarascia-Mugnozza, G.E. Schlesinger, W.H., Oren, R., 2005. Forest response to elevated $\mathrm{CO}_{2}$ is conserved across a broad range of productivity. Proc. Natl. Acad. Sci. U.S.A. 102 (50), 18052-18056.

Notaro, M., Liu, Z., Gallimore, R., Vavrus, S.J., Kutzbach, J.E., Prentice, I.C., Jacob, R.L., 2005. Simulated and observed preindustrial to modern vegetation and climate changes*. J. Clim. 18, 3650-3671.

Orlovsky, L., Kogan, F., Eshed, E., Dugarjav, C., 2011. Monitoring droughts and pastures productivity in Mongolia using NOAA-AVHRR data. In: Kogan, F. (Ed.), Use of Satellite and In-Situ Data to Improve Sustainability. Springer Science+Business Media B.V., New York, pp. 69-79.

Pederson, N., Jacoby, G., D’Arrigo, R., Cook, E., Buckley, B., 2001. Hydrometeorological reconstructions for northeastern Mongolia derived from tree rings: 1651-1995* J. Clim. 14, 872-881.

Pederson, N., Leland, C., Nachin, B., Hessl, A., Bell, A.R., Martin-Benito, D., Saladyga, T., Suran, B., Brown, P.M., Davi, N.K., 2013. Three centuries of shifting hydroclimatic regimes across the Mongolian breadbasket. Agri. Forest Meteorol., http://dx.doi.org/10.1016/j.agrformet.2012.07.003.

Peel, M.C., Finlayson, B.L., McMahon, T.A., 2007. Updated world map of the KöppenGeiger climate classification. Hydrol. Earth Syst. Sci. 11, 1633-1644.

Peng, S., Piao, S.L., Ciais, P., Fang, J., Wang, X., 2010. Change in winter snow depth and its impacts on vegetation in China. Global Change Biol. 16 (11), 3004-3013.

Penuelas, J., Canadell, J.G., Ogaya, R., 2011. Increased water-use efficiency during the 20 th century did not translate into enhanced tree growth. Global Ecol. Biogeogr. 20, 597-608.

Piao, S.L., Ciais, P., Huang, Y., Shen, S., Peng, S., Li, J., Zhou, L., Liu, H., Ma, Y., Ding, Y., Friedlingstein, P., Liu, C., Tan, K., Yu, Y., Zhang, T., Fang, J., 2010a. The impacts of climate change on water resources and agriculture in China. Nature 467 43-51.

Piao, S.L., Ciais, P., Lomas, M., Beer, C., Liu, H., Fang, J., Friedlingstein, P., Huang, Y. Muraoka, H., Son, Y., Woodward, F.I., 2010b. Contribution of climate change and 
rising $\mathrm{CO}_{2}$ to terrestrial carbon balance in East Asia: a multi-model analysis. Global Planet. Change 75 (3-4), 133-142.

Piao, S.L., Fang, J., Liu, H., Zhu, B., 2005. NDVI-indicated decline in desertification in China in the past two decades. Geophys. Res. Lett. 32 (L06402), http://dx.doi.org/10.1029/2004GL021764.

Piao, S.L., Ito, A., Li, S., Huang, Y., Ciais, P., Wang, X., Peng, S., Nan, H., Zhao, C., Ahlstrom, A., Andres, R.J., Chevallier, F., Fang, J., Hartmann, J., Huntingford, C., Jeong, S., Levis, S., Levy, P.E., Lomas, M., Mao, J., Mohammat, A., Muraoka, H., Peng, C., Peylin, P., Poulter, B., Xhi, S., Sitch, S., Tao, S., Tian, H., Xu, M., Yu, G., Viovy, N., Zaehle, S., Zeng, N., Zhu, B., 2012. The carbon budget of terrestrial ecosystems in East Asia over the last two decades. Biogeosciences, 4025-4066.

Potter, C., Klooster, S., Myneni, R., Genovese, V., Tan, P.N., Kumar, V., 2003. Continental-scale comparisons of terrestrial carbon sinks estimated from satellite data and ecosystem modeling 1982-1998. Global Planet. Change 39, 201-213.

Potter, C., Kumar, V., Klooster, S., Nemani, R., 2007. Recent history of trends in vegetation greenness and large-scale ecosystem disturbances in Eurasia. Tellus 59B, 260-272.

Poulter, B., Aragao, L., Heinke, J., Gumpenberger, M., Heyder, U., Rammig, A., Thonicke, K., Cramer, W., 2010. Net biome production of the Amazon Basin in the 21st century. Global Change Biol., http://dx.doi .org/10.1111/j. 1365-2486.2009.02064.x.

Poulter, B., Ciais, P., Hodson, E.L., Lischke, H., Maignan, F., Plummer, S., Zimmermann, N.E., 2011. Plant functional type mapping for earth system models. Geosci. Model Dev. 4, 993-1010.

Poulter, B., Heyder, U., Cramer, W., 2009. Modelling the sensitivity of the seasonal cycle of GPP to dynamic LAI and soil depths in tropical rainforests. Ecosystems 12 (4), 517-533.

Prentice, I.C., Bondeau, A., Cramer, W., Harrison, S.P., Hickler, T., Lucht, W., Sitch, S., Smith, B., Sykes, M.T., 2007. Dynamic global vegetation modeling: quantifying terrestrial ecosystem responses to large-scale environmental change. In: Canadell, P., Pataki, D.E., Pitelka, L.F. (Eds.), Terrestrial Ecosystems in a Changing World. Springer-Verlag, Berlin, Heidelberg, DE, pp. 175-192.

Rotenberg, E., Yakir, D., 2010. Contribution of semi-arid forests to the climate system. Science 327 (5964), 451-454.

Ryan, M.G., 1991. Effects of climate change on plant respiration. Ecol. Appl. 1 (2), 157-167.

Sankaran, M., Hanan, N.P., Scholes, R.J., Ratnam, J., Augustine, D.J., Cade, B.S., Gignoux, J., Higgins, S., Le Roux, X., Ludwig, F., Ardo, J., Banyikwa, F., Bronn, A., Bucini, G., Caylor, K.K., Coughenour, M.B., Diouf, A., Ekaya, W., Feral, C.J., February, E.C., Frost, P.G.H., Hiernaux, P., Hrabar, H., Metzger, K.L., Prins, H.H.T., Ringrose, S., Sea, W., Tews, J., Worden, J., Zambatis, N., 2005. Determinants of woody cover in African savannas. Nature 438, 846-849.

Schaefer, K., Schwalm, C.R., Williams, C., Arain, M.A., Barr, A., Chen, J.M., Davis, K.J., Dimitrov, D., Hilton, T.W., Hollinger, D.Y., Humphreys, E., Poulter, B., Raczka, B.M., Richardson, A.D., Sahoo, A., Thornton, P., Vargas, R., Verbeeck, H., Anderson, R.G., Baker, I., Black, T.A., Bolstad, P.V., Chen, J., Curtis, P.S., Desai, A.R., Dietze, M.C., Dragoni, D., Gough, C.M., Grant, R.F., Gu, L., Jain, A.K., Kucharick, C.J., Law, B.E., Liu, S., Lokipitiya, E., Margolis, H., Matamala, R., McCaughey, J.H., Monson, R.K., Munger, J.W., Oechel, W.C., Peng, C., Price, D.T., Ricciuto, D.M., Riley, W.J., Roulet, N.T., Tian, H., Tonitto, C., Torn, M., Weng, E., Zhou, X., 2012. A model-data comparison of gross primary productivity: results from the North American Carbon Program site synthesis. J. Geophys. Res. 117 (G03010), http://dx.doi.org/10.1029/2012JG001960.
Scholze, M., Knorr, W., Arnell, N.W., Prentice, I.C., 2006. A climate-change risk analysis for world ecosystems. Proc. Natl. Acad. Sci U.S.A. 103, 13116-13120.

Schwalm, C.R., Williams, C.A., Schaefer, K., Anderson, R., Arain, M.A., Baker, I., Barr, A., Black, T.A., Chen, G., Chen, J.M., Ciais, P., Davis, K.J., Desai, A.R., Dietze, M.C., Dragoni, D., Fischer, M.L., Flanagan, L.B., Grant, R.F., Gu, L., Hollinger, D.Y., Izaurralde, R.C., Kucharick, C.J., Lafleur, P., Law, B.E., Li, L., Li, Z., Liu, S., Lokipitiya, E., Luo, Y., Ma, S., Margolis, H., Matamala, R., McCaughey, J.H., Monson, R.K. Oechel, W.C., Peng, C., Poulter, B., Price, D.T., Ricciuto, D.M., Riley, W.J., Sahoo, A.K., Sprintsin, M., Sun, J., Tian, H., Tonitto, C., Verbeeck, H., Verma, S.B., 2010. A model-data intercomparison of $\mathrm{CO}_{2}$ exchange across North America: results from the North American Carbon Program site synthesis. J. Geophys. Res. 115 (G00H05), http://dx.doi.org/10.1029/2009JG001229.

Shi, J., Liu, Y., Yang, Y., Cai, Q., Kirdyanov, A.V., 2004. The reconstruction of tree-ring chronology and their climate meaning in Zhungeerqi county, Inner Mongolia (in Chinese with English abstract). Mar. Geol. Quatern. Geol. 24 (3), 123-128.

Sitch, S., Smith, B., Prentice, I.C., Arneth, A., Bondeau, A., Cramer, W., Kaplan, J.O., Levis, S., Lucht, W., Sykes, M.T., Thonicke, K., Venevsky, S., 2003. Evaluation of ecosystem dynamics, plant geography and terrestrial carbon cycling in the LPJ dynamic global vegetation model. Global Change Biol. 9, 161-185.

Thonicke, K., Venevsky, S., Sitch, S., Cramer, W., 2001. The role of fire disturbance for global vegetation dynamics: coupling fire into a Dynamic Global Vegetation Model. Global Ecol. Biogeogr. 10, 661-677.

Tucker, C.J., Pinzon, J.E., Brown, M.E., Slayback, D.A., Pak, E.W., Mahoney, R., Vermote, E.F., El Saleous, N., 2005. An extended AVHRR 8-km NDVI dataset compatible with MODIS and SPOT vegetation NDVI data. Int. J. Remote Sens. 26 (20), 44854498.

Vaganov, E., Hughes, M., Kirdyanov, A., Schweingruber, F., Silkin, P., 1999. Influence of snowfall and melt timing on tree growth in Subarctic Eurasia. Nature 400, 149-151.

Vicca, S., Luyssaert, S., Penuelas, J., Campioli, M., Chapin, F.S., Ciais, P., Heinemeyer, A., Hogberg, P., Kutsch, W.L., Law, B.E., Malhi, Y., Papale, D., Piao, S.L., Reichstein, M., Schulze, E.D., Janssens, I.A., 2012. Fertile forests produce biomass more efficiently. Ecol. Lett. 15, 520-526.

Wang, M., Dai, J., Bai, J., Cui, H., 2009a. Humidity changes since 1900 in the Liupan Mountains using tree-ring width (in Chinese with English abstract). J. Paleogeogr. 11, 355-360.

Wang, Y., Ma, Y., Zheng, Y., Lu, R., Sang, Y., Meng, H., 2009b. Response of tree-ring width of Pinus tabulaeformis to climate factors in Luoshan Mountains of Ningxia. J. Desert Res. 29, 971-976 (in Chinese with English abstract).

Williams, A.P., Xu, C., McDowell, N., 2011. Who is the new sheriff in town regulating boreal forest growth? Environ. Res. Lett. 6, 041004.

Yi, L., Liu, Y., Song, H., Li, Q., Cai, Q., Yang, Y., Sun, J., 2006. Summer Temperaure Variations since $1676 \mathrm{AD}$ in Luya Mountain, Shanxi Province of China, inferred from Tree Rings. J. Glaciol. Geocryol. 28, 330-336 (in Chinese with English abstract).

Zhao, M., Running, S.W., 2010. Drought-induced reduction in global terrestrial net primary production from 2000 through 2009. Science 329 (5994), 940943.

Zhu, Z., Bi, J., Pan, Y., Ganguly, S., Anav, A., Xu, L., Samanta, A., Piao, S., Nemani, R.R., Myneni, R., 2012. Global data sets of vegetation LAI3g and FPAR3g derived from GIMMS NDVI3g for the period 1981 to 2011. Remote Sensing.

Zobler, L., 1986. A world soil file for global climate modeling. NASA Technical Memorandum, $32 \mathrm{pp}$. 